\title{
Bioprospecting of Palmyra Palm (Borassus flabellifer) Nectar: Unveiling the Probiotic and Therapeutic Potential of the Traditional Rural Drink
}

\section{OPEN ACCESS}

Edited by:

Vincenzina Fusco,

Italian National Research Council, Italy

Reviewed by:

Olga Papadopoulou,

Hellenic Agricultural Organization,

Greece

Carmen Wacher,

National Autonomous University

of Mexico, Mexico

*Correspondence:

Bhima Bhukya

bhima.ou@osmania.ac.in

Specialty section:

This article was submitted to

Food Microbiology,

a section of the journal

Frontiers in Microbiology

Received: 22 March 2021 Accepted: 04 June 2021

Published: 28 June 2021

Citation:

Pammi N, Bhukya KK, Lunavath RK and Bhukya B (2021)

Bioprospecting of Palmyra Palm (Borassus flabellifer) Nectar: Unveiling the Probiotic and Therapeutic

Potential of the Traditional Rural Drink. Front. Microbiol. 12:683996.

doi: 10.3389/fmicb.2021.683996

\section{Nagamani Pammi, Kiran Kumar Bhukya, Ravi Kumar Lunavath and Bhima Bhukya*}

Centre for Microbial and Fermentation Technology, Department of Microbiology, University College of Science, Osmania University, Hyderabad, India

The present study investigates the therapeutic and probiotic attributes of traditional Toddy Palm Nectar (TPN). Glucose was found to be the highest with $4.37 \mathrm{mg} / \mathrm{ml}$ and arabinose was the least with $2.85 \mathrm{mg} / \mathrm{ml}$. The average ethanol concentration of fresh TPN was found to be $0.3 \mathrm{mg} / \mathrm{ml}$. The nutritional profile of TPN revealed 18 volatile fatty acids, the major one being hexadecenoic acid (M/Z 74). Amino acid profiling showed 26 amino acids, with $\mathrm{OH}$-lysine-2 the highest (12.86\%). About 120 morphologically distinct lactic acid bacteria $(\llcorner A B)$ were isolated from 26 TPN samples, based on differential growth and in vitro probiotic characteristics. After 16S rRNA sequencing, four indigenous LAB strains were identified as Lactobacillus plantarum group OUBN1, Enterococcus faecium OUBN3, Pediococcus acidilactici OUBN4, and Pediococcus pentosaceous OUBN5 and their sequences were deposited to NCBI. Microbiological safety evaluation studies showed the absence of hemolytic, gelatinolytic and proteolytic activity. The bacterial isolate OUBN3 showed a maximum survival rate of $6.91 \pm 0.04 \mathrm{log} \mathrm{cfu} / \mathrm{ml}$ at acidic $\mathrm{pH} 2.5$ and isolate OUBN5 showed $6.94 \pm 0.02$ $\log \mathrm{cfu} / \mathrm{ml}$ at $\mathrm{pH}$ 3.0. Similarly, the isolate OUBN5 showed $7.92 \pm 0.03 \mathrm{log} \mathrm{cfu} / \mathrm{ml}$ to $0.3 \%$ ox-bile after $4 \mathrm{~h}$ and $8.94 \pm 0.03 \mathrm{log} \mathrm{cfu} / \mathrm{ml}$ to simulated gastric juice after $3 \mathrm{~h}$ of treatments. OUBN1 expressed the highest autoaggregation (81.76 $\pm 1.25 \%$ ), cell surface hydrophobicity $(79.71 \pm 3.42 \%)$, and displayed the maximum coaggregation with E. coli MTCC452 (76.96\%), K. pneumoniae MTCC109 (75.62\%), and S. aureus MTCC902 (70.69\%). All strains showed significant antibiotic and antimicrobial activity. Isolate OUBN1 displayed hydroxyl radical scavenging activity (68.71 $\pm 1.0 \%)$ with an $\mathrm{IC}_{50}$ value of $75.62 \mu \mathrm{g} / \mathrm{ml}$ and the highest anti-cancer activity (percentage inhibition of 88.55) against HT-29 cells. Based on the characteristics observed, L. plantarum group OUBN1 and $P$. pentosaceous OUBN5 were found to be potential isolates to employ as probiotic microbiota in food and forage preparations. These findings reinforce the fact that LAB isolated from TPN could be exploited as an alternative means toward potential therapeutic applications.

Keywords: probiotics, lactic acid bacteria, toddy palm nectar, volatile fatty acids, amino acids 


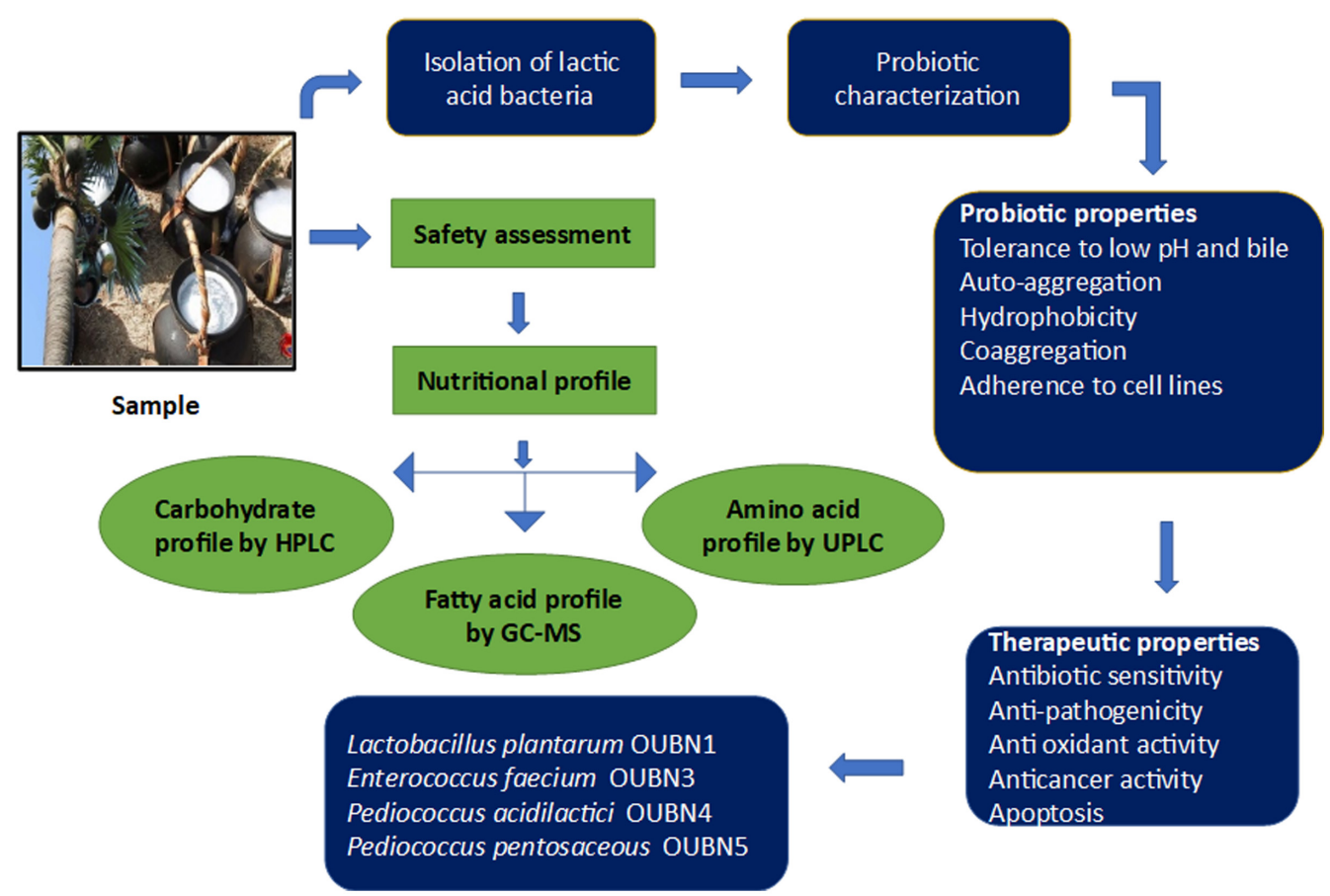

GRAPHICAL ABSTRACT |

\section{INTRODUCTION}

Fermented plant-based beverages have been persistent in human societies for ages (Lamba et al., 2019). Among them, toddy palm nectar (TPN) is one of the renowned naturally fermented seasonal traditional alcoholic beverages consumed in various regions of rural India. Due to growing lactose intolerance and allergy to milk and milk-based products, consumers are intensely demanding functional probiotic products from natural sources such as fruits, vegetables, and cereals (Sornplang and Piyadeatsoontorn, 2016).

Therefore, more attention toward fermented products of plant origin is a need of the hour (Coutiño et al., 2020). It is noteworthy that TPN represents a traditional rural drink of the Indian society for ages. Owing to the vital role it has occupied in traditional culture, it is necessary to understand the microbiological and biochemical nature of TPN, as not many studies have been conducted on probiotics and nutritional aspects of it.

TPN is a naturally fermented sap from young and matured inflorescences of Borassus flabellifer Linn. (Palmyra Palm), belongs to the family Arecaceae, and is commonly referred to as "toddy" (Zeid and FarajAlla, 2019). As a traditional energizing drink with significant health-promoting effects, TPN is enjoyed by people in parts of South America, Africa, and Asia (Reshma et al., 2017). Local names of the product include kallu in southern India, emu, and ogogoro in Nigeria, nsafufuo in Ghana, and tuba in Mexico. Fresh TPN is a colorless sweet-flavored drink with a $\mathrm{pH}$ between 6.0 and 7.0, which contains various carbohydrates and proteins. Generally, it contains reducing and non-reducing sugars, ethanol, and various nutrients including volatile fatty acids (VFAs), amino acids, and flavonoids (Lasekan and Abbas, 2010). It is also a good source of ascorbic acid, nicotinic acid, vitamin A, riboflavin, several minerals, and salts (Morton, 1988; Chinnamma et al., 2019). As a folk medicine, TPN obtained from the flower stalks of palm trees can be used as a tonic, stimulant, laxative, diuretic, anti-phlegmatic, and amebicide (Lim, 2012; Mariselvam et al., 2020).

Volatile fatty acids have several applications in the food, healthcare, and pharmaceutical industries and their derivatives are used as anticonvulsants in neurodegenerative diseases as neuroprotective agents (Lei et al., 2016). VFAs help to regulate insulin secretion and indirectly affect cholesterol synthesis. Plantderived amino acids are important dietary bioactive components for human and animal nutrition. Essential amino acids have been recognized as nutrient regulators in muscle protein synthesis and tissue regeneration. Therefore, estimation of these nutritional attributes is essential for the development of plant-based foods (Tayade et al., 2017).

Fresh TPN collected under hygienic conditions during the early hours of a day is known to contain various probiotic strains of yeast and bacteria (Somashekaraiah et al., 2019). It is reported that TPN could be a potential source of probiotic LAB like Lactobacillus, Lactococcus, Leuconostoc, Enterococcus, Pediococcus, and Streptococcus, etc. (Amoa-Awua et al., 2007; Somashekaraiah et al., 2019). Bacteria related to Lactobacillus, Pediococcus, and Bifidobacterium are predominant groups used in many dietary supplements and functional foods (Pandey et al., 2015). Ideal probiotics must exhibit in vitro characteristics, such as tolerance to low $\mathrm{pH}$, bile, gastric juice, antibiotics and efficiently adhere to intestinal epithelial cells. It must also 
obey other technical qualities such as auto-aggregation, coaggregation, cell surface hydrophobicity, vigorous antimicrobial activity against enteric pathogens, and boosting the immune response (Saadat et al., 2019). Antioxidant and anticancer properties provide a potential platform for their therapeutic applications (Barigela and Bhukya, 2021). The influence of LAB against enteric pathogens, reducing toxicity and increasing nutritive value of fermented foods has been studied by Bartkiene et al. (2018). Numerous probiotic studies have shown promising results in improving health ailments such as anxiety, depression (Aslam et al., 2020), antibiotic-related diarrhea, irritable bowel syndrome (Sanders et al., 2019), and alleviation of lactose intolerance (Aspri et al., 2020).

The prime objective of the current study is to gain awareness and explore the nutritional and probiotic qualities of TPN. Selected LAB were analyzed for their in vitro probiotic attributes to confirm their potential health benefits and therapeutic applications.

\section{MATERIALS AND METHODS}

\section{Sample Collection and Processing}

Twenty-six fresh samples of toddy palm nectar (TPN) were collected from different geographical areas of Telangana, India in sterilized polythene bags under hygienic conditions and brought to the laboratory in an icebox at $4^{\circ} \mathrm{C}$, without exposure to the sun. One set of samples was directly stored in the refrigerator and another set of samples were centrifuged at 10,000 rpm for $10 \mathrm{~min}$, supernatants were filtered through a $0.22 \mu \mathrm{m}$ membrane filter (Sartorius AG, Göttingen, Germany) and stored at $-20 \circ \mathrm{C}$ for further analysis. The $\mathrm{pH}$ of TPN samples was determined using a $\mathrm{pH}$ meter (Systronics, India).

\section{Chemical Profile of Toddy Palm Nectar Evaluation of Total Sugars and Ethanol by HPLC}

Total sugars and ethanol from fresh TPN were analyzed on HPLC (Shimadzu Inc.) with the method described by Lefebvre et al., 2002. Analysis was performed under isocratic conditions using a platinum amino column $(250 \times 4.6 \mathrm{~mm}, 5 \mu \mathrm{m})$ and a photodiode array detector (PDA) maintained at $40^{\circ} \mathrm{C}$. The mobile phase consisted of $0.001 \mathrm{~N} \mathrm{H}_{2} \mathrm{SO}_{4}$ was pumped with a flow rate of $1 \mathrm{ml} / \mathrm{min}$ with an injection volume of $20 \mu \mathrm{l}$. The eluent and samples were filtered using $0.22 \mu \mathrm{m}$ nylon membrane filters (Sartorius AG, Göttingen, Germany) prior to analysis. All chemicals used were of HPLC grade and supplied by SigmaAldrich. Elution was monitored at $215 \mathrm{~nm}$. Ethanol and different sugars like sucrose, fructose, glucose, galactose, lactose, arabinose, raffinose were identified by comparing the retention times with authentic standards and their concentrations were determined.

\section{Evaluation of Volatile Fatty Acids by GC-MS Analysis}

Gas chromatography and mass spectrometry (GC-MS) analysis were carried out as described by Dos Santos et al., 2011 using GCMS-QP2010 PLUS (Shimadzu, Japan) with DB5 MS $(0.25 \times 30 \times 0.25)$ column. Helium (carrier) was used at a rate of $1 \mathrm{ml} / \mathrm{min}$ and an injection volume of $1 \mu \mathrm{l}$ was used with an injector temperature of $280^{\circ} \mathrm{C}$ and ion-source temperature of $200^{\circ} \mathrm{C}$. The temperature was maintained at $100^{\circ} \mathrm{C}$ (isothermal for $4 \mathrm{~min}$ ), with an increase of $10^{\circ} \mathrm{C} / \mathrm{min}$, up to $200^{\circ} \mathrm{C}$. The temperature was then raised at a level of $4^{\circ} \mathrm{C}$ until it reached $280^{\circ} \mathrm{C}$ and maintained for $12.95 \mathrm{~min}$. The sample was prepared by mixing $500 \mu \mathrm{l}$ of TPN with $200 \mu \mathrm{l}$ chloroform, vortexed for $5 \mathrm{~min}$ and allowed to settle, followed by centrifugation at 4,000 rpm for $10 \mathrm{~min}$. The chloroform layer was collected, and the above step was repeated three times After each step, chloroform layers were pooled and dried under vacuum. Derivatization was carried out for the speed vac dried pellet with methanol and heated at $60 \circ \mathrm{C}$ for $20 \mathrm{~min}$. Subsequently, $1 \mathrm{ml}$ of chloroform was added and after a short spin, approximately $100 \mu \mathrm{l}$ of chloroform layer was taken for injection. Mass spectra were recorded at two scans per second with a scanning interval of $50-600 \mathrm{~m} / \mathrm{z}$. Compounds were identified based on GC retention times and compared with standard mass spectra using the Wiley and NIST (National Institute of Standards and Technology) Librarie 11.

\section{Estimation and Quantification of Amino Acids by Ultra-Performance Liquid Chromatography (UPLC)}

Amino acid profiling was carried out by UPLC (Waters Acquity) equipped with a PDA detector according to the previous protocol (Szkudzińska et al., 2017). The column temperature was maintained at $55 \circ \mathrm{C}$ and $260 \mathrm{~nm}$ wavelength with a flow rate of $0.7 \mathrm{ml} / \mathrm{min}$. In brief, $2 \mathrm{ml}$ of $6 \mathrm{M} \mathrm{HCL}$ was taken into a $50 \mathrm{ml}$ flat bottom tube containing internal standard. Hundred microliter of the test sample was taken into a separate clean glass vial and inserted into a flat bottom tube. The tube was sealed with parafilm and placed in a dry bath at $60^{\circ} \mathrm{C}$ under $\mathrm{N}_{2}$ gas for $15 \mathrm{~min}$, to maintain inertness. The temperature of the dry bath was gradually increased to $110^{\circ} \mathrm{C}$ and the incubation was extended till $24 \mathrm{~h}$ to get the pellet. Borate buffer $(200 \mu \mathrm{l})$ was added to the pellet, vortexed, and centrifuged. Later $10 \mu \mathrm{l}$ of sample from the supernatant was added with $70 \mu \mathrm{l}$ of borate buffer and $20 \mu \mathrm{l}$ of Accq Tag ultra-reagent and incubated for $10 \mathrm{~min}$ at $55^{\circ} \mathrm{C}$ for derivatization. After incubation, $1 \mu \mathrm{l}$ was loaded into UPLC and quantified using amino acid standards (Sigma).

\section{Isolation and Screening of LAB From TPN Samples}

From 26 TPN samples, $1 \mathrm{ml}$ each was added to de Man, Rogosa, and Sharpe (MRS) broth and incubated at $37 \circ \mathrm{C}$ for $24 \mathrm{~h}$ in aerobic conditions, and a further 10- fold dilution was made up to $10^{-7}$ by adding phosphate buffer saline (PBS). Aliquots of $0.1 \mathrm{ml}$ of each dilution were seeded on MRS agar plates containing $\mathrm{CaCO}_{3}$ by the spread plate method (Xiao et al., 2015) to distinguish acid-producing bacteria. The bacterial colonies forming clear zones due to the hydrolysis of $\mathrm{CaCO}_{3}$ around them were considered as LAB and were individually picked and streaked on MRS agar for further screening. After incubation, 120 morphologically discrete colonies were randomly selected, obtained LAB isolates were subcultured on MRS agar plates and stored at $4^{\circ} \mathrm{C}$ for further characterization. All LAB isolates were examined by Gram staining, Catalase test, their tolerance to salts and temperature was evaluated and morphology was studied by microscopic observation. Isolates were cultured at different 
temperatures $\left(10-45^{\circ} \mathrm{C}\right)$ and different concentrations of $\mathrm{NaCl}(2$, $4,6 \% \mathrm{w} / \mathrm{v}$ ) (Ni et al., 2015).

\section{Molecular Identification of LAB Isolates}

Extraction of bacterial genomic DNA was done using the MagGenome XpressDNA isolation kit (India). Amplification of $16 \mathrm{~S}$ rRNA was performed using a primer set of 27F (5AGAGTTTGAYCCTGGCTCAG- $\left.{ }^{\prime}\right)$ and 1492R (5'GGCTACCTTGTTACGACTT-3') (Macrogen, South Korea). Obtained sequences were compared with the data available in the GenBank database by NCBI-BLAST (Altschul et al., 1997). The phylogenetic tree was constructed using the Neighbor-joining method with Mega X software (Saitou and Nei, 1987) and sequences were submitted to NCBI.

\section{Safety Evaluation}

Hemolytic, proteolytic and gelatinase activities of TPN microflora was evaluated by inoculating the TPN and overnight grown cultures of LAB isolates in Columbia blood agar (BD, Difco), MRS agar supplemented with $1 \%$ skimmed milk powder and MRS agar (Himedia, India) supplemented with 5\% (w/v) gelatin (HiMedia, India), respectively, and incubating at $37^{\circ} \mathrm{C}$ under aerobic conditions for $48 \mathrm{~h}$. After incubation, plates were observed for hemolytic properties viz. $\alpha$-hemolysis (greenish clear zone around the colony), $\beta$-hemolysis (clear zone around the colony) and, $\gamma$-hemolysis (no clear zone around the colony) (Yasmin et al., 2020). The presence of a clear zone around the colonies in skimmed milk supplemented medium was considered positive for proteolytic activity (Da Silva et al., 2019). Gelatinase activity was observed in gelatin supplemented medium after $72 \mathrm{~h}$. of incubation and subsequently, plates were kept at $4^{\circ} \mathrm{C}$ for $4 \mathrm{~h}$ to observe the clear zone around the colonies as a positive result (Perin et al., 2014). A multiple tube fermentation test was carried out to check the coliform contamination (Mannapperuma et al., 2011). TPN samples were inoculated, incubated at $37^{\circ} \mathrm{C}$ aerobically for $48 \mathrm{~h}$ in MacConkey broth (Himedia, India) to activate coliforms. These active cultures were added to the Brilliant Green Lactose Bile broth (Himedia, India) embedded with Durhams tubes, then incubated at $37^{\circ} \mathrm{C}$ for $48 \mathrm{~h}$. Coliforms can be confirmed by observing gas production in inverted Durhams tubes and the appearance of a red ring after adding $0.2 \mathrm{ml}$ of Kovac's reagent to the Brilliant Green Lactose Bile broth.

\section{Evaluation of Probiotic Properties}

LAB isolates were evaluated in vitro for their probiotic potential.

\section{Acid and Bile Tolerance}

Tolerance to acidic $\mathrm{pH}$ was carried out with the methodology described by Zommiti et al. (2018). The overnight grown cultures of $\mathrm{LAB}$ isolates were inoculated in MRS broth with $\mathrm{pH}$ adjusted to 2.5 and 3.0 using $1 \mathrm{~N}$ Hydrochloric acid (HCL) and incubated aerobically at $37 \circ \mathrm{C}$ for $3 \mathrm{~h}$. The MRS broth with initial $\mathrm{pH}$ of 6.5 was considered as a control for acidic $\mathrm{pH}$ comparison. Samples were collected at every $1 \mathrm{~h}$ interval to check for the viability of isolates for $3 \mathrm{~h}$ and calculated the $\log \mathrm{cfu} / \mathrm{ml}$. Bile salt tolerance of isolates was carried out using the protocol of de Albuquerque et al. (2018). The overnight grown LAB cultures were inoculated in MRS broth supplemented with $0.3 \%(w / v)$ Oxgall and incubated at $37^{\circ} \mathrm{C}$ for $4 \mathrm{~h}$. MRS broth without bile salt was used as a control for comparison. Samples were collected at every $1 \mathrm{~h}$ interval, serially diluted, plated on MRS agar, and incubated at $37^{\circ} \mathrm{C}$ for $48 \mathrm{~h}$ and viable cell counts (log cfu/ml) were determined.

\section{Survival in Simulated Gastric Juice}

Subsequently, the selected isolates from each of the above experiments were further tested to determine their ability to survive in a gastric environment by inoculating them in simulated gastric juice as described by Singhal et al., 2019. Five $\mathrm{ml}$ of overnight grown cultures of LAB strains were centrifuged, and the bacterial pellet was washed and re-suspended in $4 \mathrm{ml}$ of saline $(0.8 \% \mathrm{NaCl})$. To the $1 \mathrm{ml}$ of cell suspension, $9 \mathrm{ml}$ of simulated gastric juice $(\mathrm{pH} 3)$ was added and vortexed for $15 \mathrm{~s}$. After incubation for 1,2 , and $3 \mathrm{~h}$, cells were harvested by taking $1 \mathrm{ml}$ of sample broth into sterile $2 \mathrm{ml}$ Eppendorf tube, then centrifuged at $10,000 \mathrm{rpm}$ for $5 \mathrm{~min}$. Viable counts were determined by growing on MRS agar incubated at $37^{\circ} \mathrm{C}$ for $24 \mathrm{~h}$. Cell viability (log cfu $/ \mathrm{ml}$ ) was assessed using the plate count method. MRS medium without simulated gastric juice was used as a control. Survival (\%) of the organisms was calculated as follows: \% Survival $=(\log$ no of viable cells survived/log no of initially viable cells $) \times 100$.

\section{Auto Aggregation, Coaggregation and Cell Surface Hydrophobicity}

Auto aggregation and coaggregation ability of $\mathrm{LAB}$ isolates were carried out by the method of Choi et al. (2018). For autoaggregation, overnight grown LAB cultures were harvested, washed, and re-suspended in PBS. The optical density of suspension was adjusted to 0.50 at $600 \mathrm{~nm}\left(\mathrm{OD}_{600}\right)$ and incubated aerobically at $37^{\circ} \mathrm{C}$ without agitation. $\mathrm{OD}_{600}$ was measured after $24 \mathrm{~h}$ of incubation, and the percent aggregation was determined as follows: $\mathrm{A} \%=\left(1-\mathrm{At} / \mathrm{A}_{0}\right) \times 100$, where $\mathrm{A} 0$ and At refers to the $\mathrm{OD}_{600}$ at $0 \mathrm{~h}$ and at the indicated time, respectively.

The ability of LAB isolates to aggregate with enteric pathogens like Escherichia coli MTCC 452, Salmonella enterica ser. paratyphi MTCC 3216, Enterococcus faecalis MTCC 6845, Proteus vulgaris MTCC426, and Klebsiella pneumoniae MTCC 109 was studied. Equal volumes of the LAB cultures and selected pathogenic bacteria were mixed after adjusting the $\mathrm{OD}_{600}$ to 0.5 . The coaggregation was expressed as the percentage reduction in the absorbance of the mixed suspension compared to the individual suspensions by taking the $\mathrm{OD}_{600}$ after 6 and $24 \mathrm{~h}$ incubation. The growth rate of pathogenic bacteria without adding cell-free supernatant (CFS) was considered as 100\% (control).

Further, LAB isolates were also assessed for cell surface hydrophobicity, by measuring adhesion capacity to hydrocarbons (Rokana et al., 2018). Overnight cultures were harvested by centrifugation at $8,000 \mathrm{rpm}, 4 \circ \mathrm{C}$ for $10 \mathrm{~min}$, and the pellet was washed twice with PBS and re-suspended in the same buffer followed by measurement of $\mathrm{OD}_{600}$. Three milliliter of cell suspension was blended with $1 \mathrm{ml}$ of hydrocarbon (xylene) and incubated without shaking at $37 \circ \mathrm{C}$ for $1 \mathrm{~h}$ to get aqueous and organic phases separately. One milliliter of the aqueous phase was removed carefully and the $\mathrm{OD}_{600}$ was measured. Cell surface 
hydrophobicity was calculated using the following formula: Cell surface hydrophobicity $\%=\left(1-\mathrm{A}_{1} / \mathrm{A}_{0}\right] \times 100$.

\section{Antibiotic Sensitivity}

The antibiotic sensitivity of selected LAB isolates was assessed by the disc diffusion method (Singhal et al., 2019). Antibiotic discs of Penicillin-G (10 units), ampicillin (AMP $10 \mu \mathrm{g}$ ), polymyxin-B (300 units), vancomycin (VA $30 \mu \mathrm{g}$ ), amoxicillin (AMX $10 \mu \mathrm{g}$ ),

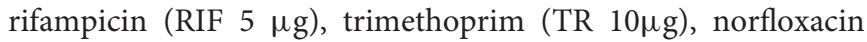
(NX $10 \mu \mathrm{g}$ ), ciprofloxacin (CIP $5 \mu \mathrm{g}$ ), streptomycin (S $10 \mu \mathrm{g}$ ), chloramphenicol (C $30 \mu \mathrm{g}$ ), tetracycline (TE $30 \mu \mathrm{g}$ ), clindamycin (CD $2 \mu \mathrm{g}$ ), erythromycin (E $15 \mu \mathrm{g}$ ), lincomycin (L $10 \mu \mathrm{g}$ ), kanamycin ( $\mathrm{K} \quad 30 \mu \mathrm{g}$ ) and gentamycin (GEN $10 \mu \mathrm{g}$ ) were chosen based on the recommendations of European Security Food Authority (EFSA Panel on Additives and Products or Substances used in Animal Feed (FEEDAP), 2012). Hundred microliter of overnight grown cultures of LAB were spread onto the MRS medium plates, allowed to dry and antibiotic discs were placed, then incubated aerobically at $37 \circ \mathrm{C}$ for $24 \mathrm{~h}$. The diameter of the clear zone of inhibition was measured using an antibiotic zone scale. Results obtained were expressed as sensitivity/resistance in $\mathrm{mm}$.

\section{Antimicrobial Activity Against Enteric Pathogens}

The antimicrobial feature of LAB isolates against enteric pathogens was assessed using the agar well diffusion method (Yadav et al., 2016). Indicator organisms like Escherichia coli MTCC452, Salmonella enterica ser. paratyphi MTCC 3216, Pseudomonas aeruginosa MTCC424, Enterococcus faecalis MTCC 6845, Proteus vulgaris MTCC426, and Klebsiella pneumoniae MTCC109 were incubated in Luria-Bertani broth for $24 \mathrm{~h}$, diluted until it gets the $\mathrm{OD}_{600}$ of 0.06 , then spread on Muller Hinton agar. Neutralized cell-free supernatant (nCFS) was prepared by centrifuging overnight cultures of $\mathrm{LAB}$ isolates at $10,000 \times$ $\mathrm{g} / 10 \mathrm{~min}$ at $4^{\circ} \mathrm{C}$, and the $\mathrm{pH}$ of the supernatant was adjusted to 6.5 using $5 \mathrm{M} \mathrm{NaOH}$. Another set of CFS without neutralization was also prepared to differentiate the impact of $\mathrm{pH}$. Subsequently, $30 \mu \mathrm{l}$ of cell-free supernatant (CFS) of LAB cultures were placed in each well and incubated for $24 \mathrm{~h}$ at $37^{\circ} \mathrm{C}$ to determine the zone of inhibition around the well.

\section{Antioxidant Assay}

$\mathrm{DPPH}$ radical scavenging ability of $\mathrm{LAB}$ was assessed by the method described by Xing et al. (2015). Briefly, $100 \mu \mathrm{l}$ of freshly prepared $0.2 \mathrm{mM}$ DPPH solution (in methanol) was added to 96- well plate comprising different concentrations of sample, then made up to $200 \mu \mathrm{l}$ with distilled water. The sample was vortexed and kept at $37 \circ \mathrm{C}$ for $30 \mathrm{~min}$ in dark. Blank was prepared by replacing DPPH with methanol. Scavenged DPPH was examined by determining the absorbance at $517 \mathrm{~nm}$ against a blank on a microplate reader (Epoch Biotech). Ascorbic acid was used as standard and methanol along with DPPH served as control. $\mathrm{IC}_{50}$ values were calculated from the data to find out the concentration of sample required to eliminate DPPH free radicals by $50 \%$. Percentage inhibition to scavenge the DPPH radicals was calculated using the following formula:

$\mathrm{DPPH}$ activity $(\mu \mathrm{l} / \mathrm{ml})=[($ Ao-Ae $) / \mathrm{Ao}] \times 100$ where, Ao and Ae are the absorbance of the control and test samples, respectively.

\section{Cell Culture and Adhesion Assay}

HT-29 cell lines (human colon adenocarcinoma) were obtained from National Cell Repository at NCCS (Pune, India) and maintained in a Minimum Essential Medium (MEM) supplemented with 20\% heat-inactivated Fetal Bovine Serum (FBS) and penicillin $10 \mathrm{U} / \mathrm{ml}$, then incubated at $37^{\circ} \mathrm{C}$ in a $5 \% \mathrm{CO}_{2}$ incubator. Adhesion of LAB cells to HT-29 cells was carried out by the method described by Sharma and Kanwar (2017). HT-29 cells $\left(5 \times 10^{5}\right.$ cells $\left./ \mathrm{ml}\right)$ were seeded in a sixwell plate and cultured until the cells reached the required confluence. Overnight cultures of LAB isolates were harvested, washed twice, and re-suspended in antibiotic-free Dulbecco's Modified Eagle Medium (DMEM) at a concentration of $10^{9}$ $\mathrm{cfu} / \mathrm{ml}$ and added to HT-29 cells. Later $300 \mu \mathrm{l}$ of methanol was added to each well, followed by incubation for $10 \mathrm{~min}$ at room temperature. Methanol was completely removed and cells were fixed by Giemsa staining $(0.72 \% \mathrm{w} / \mathrm{v}$; Sigma $)$ for $30 \mathrm{~min}$ at room temperature. Plates were washed with ethanol, air-dried, and bacterial adhesion was examined under an inverted microscope (Olympus BX64, Japan) at a scale of $200 \mu \mathrm{m}$.

\section{Anticancer Activity by MTT [-(4, 5-Dimethylthiazol- 2-yl)-2, 5-Diphenyltetrazolium Bromide] Assay}

Effect of CFS of LAB on HT-29 colon cancer cell lines for antiproliferation ability was evaluated by MTT assay according to the protocol of Chandel et al. (2019). Each well of the 96well plate was seeded with $5 \times 10^{5}$ cells in $200 \mu \mathrm{l} \mathrm{MEM}$. After $24 \mathrm{~h}$, CFS of LAB were added to each well in a volumedependent mode $(20,40,60,80$, and $100 \mu \mathrm{l})$ and incubated for $24 \mathrm{~h}$. After precise incubation, $50 \mu \mathrm{l}$ of MTT solution $(0.4 \mathrm{mg} / \mathrm{ml})$ was added to each well and re-incubated for $4 \mathrm{~h}$ in a $5 \% \mathrm{CO}_{2}$ incubator. After incubation, the MTT solution was replaced with $100 \mu \mathrm{l}$ of dimethyl sulfoxide to solubilize the formazan crystals and incubated for $30 \mathrm{~min}$ at $37 \circ \mathrm{C}$. The absorbance of each well was measured using an ELISA reader (Epoch Biotech microplate reader) at $570 \mathrm{~nm}$. Results were expressed as \% anti-cancer activity of LAB which was calculated as 1-(OD of test sample/OD of control)X 100. For comparison, MRS broth was taken as control. $\mathrm{IC}_{50}$ values were calculated to know the required CFS of LAB to obtain $50 \%$ anti-cancer activity.

\section{Detection of Cell Apoptosis by DAPI (4', 6-Diamidino- 2-Phenylindole) Staining}

Two $\mathrm{ml}$ of HT-29 cells $\left(1.2 \times 10^{5}\right.$ cells $\left./ \mathrm{ml}\right)$ were added to each well of a six-well plate and incubated in a $5 \% \mathrm{CO}_{2}$ incubator at $37^{\circ} \mathrm{C}$ for $48 \mathrm{~h}$. After achieving a confluence of $50-60 \%, 500 \mu \mathrm{l}$ of selected LAB-CFS was added to each well, and wells without CFS were considered as control. After $24 \mathrm{~h}$, cells were carefully washed with DMEM and then $4 \%$ formaldehyde was added. After 5 min of incubation, the fixed cells were washed twice with PBS, permeabilized, and then again treated with PBS containing $0.1 \%$ Triton X-100 for $5 \mathrm{~min}$ at $37^{\circ} \mathrm{C}$. Cells were stained with $50 \mu \mathrm{l}$ of DNA-intercalating agent DAPI (1:2,000 dilution) and incubated 
for $24 \mathrm{~h}$ at $37^{\circ} \mathrm{C}$ (Nami et al., 2015). Subsequently, the plates were washed with PBS and evaluated under an inverted microscope with a U-MWU2 fluorescence filter (Olympus BX64, Japan).

\section{Statistical Analysis}

Each experiment was carried out in triplicates. Values were statistically analyzed and expressed as mean \pm standard deviation (SD). Significant differences in the results of each test were determined by comparing relative control values by ANOVA (Analysis of Variance) using Graph Pad Prism software. $P<0.05$ was considered statistically significant.

\section{RESULTS}

\section{Chemical Analysis of Palm Nectar}

\section{Sugar, Ethanol, Fatty Acid, and Amino Acid Profile}

To understand the nutritional and therapeutic efficiency of TPN, sugar, ethanol, fatty acid (VFA), and amino acid profiling was done. Among sugars, glucose, arabinose, and galactose were detected at retention time (RT) 6.3, 6.4, and 6.2, respectively. Glucose was found to be the highest with $4.37 \mathrm{mg} / \mathrm{ml}$ and arabinose was the least with $2.85 \mathrm{mg} / \mathrm{ml}$. The average ethanol concentration of fresh TPN was found to be $0.3 \mathrm{mg} / \mathrm{ml}$. A total of 18 major VFAs were identified in the crude TPN chloroform extract on GC-MS. Among them, significant peaks were observed for hexadecenoic acid, methyl palmitate at RT $23.86(\mathrm{M} / \mathrm{Z} 74)$, E-15-heptadecenal at RT 21.17 (M/Z55) and E-14-hexadecenal at RT 16.73(M/Z55) (Table 1). Similarly, a total of 26 primary amino acids were identified in fresh TPN. OH-lysine-2 (12.86\% mole) was being the major one and alanine $(12.52 \%$ mole $)$ and leucine $(6.08 \%$ mole) were identified as the second and third major amino acids, respectively, while histidine $(0.30 \%$ mole $)$ was the lowest one (Table 2).

\section{Bacterial Isolation and Characterization}

A total of 120 bacterial isolates were obtained from twenty-six TPN samples on MRS agar with $\mathrm{CaCO}_{3}$ then further subjected to physiological and biochemical screening. Gram-positive and catalase-negative isolates were presumptively identified as LAB. The growth of four selected isolates at various salinity and temperatures showed that the isolates displayed the ability to grow in presence of $6 \% \mathrm{NaCl}$ and at $42 \circ \mathrm{C}$ except for one isolate OUBN4 (Table 3). Based on the above, these four LAB isolates were further characterized at the species level by $16 \mathrm{~S}$ rRNA sequencing analysis. Phylogeny of these four LAB isolates viz. OUBN1, OUBN3, OUBN4, and OUBN5 have shown maximum similarity with the Lactobacillus plantarum group (99.18\%), Enterococcus faecium (99.85\%), Pediococcus acidilactici (100\%), and Pediococcus pentosaceous (98.33\%), respectively (Figure 1). Sequences were submitted to the NCBI GenBank database and accession numbers were obtained for the gene sequences of isolate OUBN1 (MF992176), OUBN3 (MF992189), OUBN4 (MF992177), and OUBN5 (MF992178).

\section{Safety Evaluation}

TPN samples were analyzed for their microbiological safety to confirm their plausibility as a safe drink. In our study,
TABLE 1 | Volatile fatty acid composition of toddy palm nectar detected by GC-MS (gas chromatography and mass spectrometry).

\begin{tabular}{|c|c|c|c|c|}
\hline Name of the compound & RT & $M / Z$ & Area & Biological importance \\
\hline $\begin{array}{l}\text { Triethyl ester (CAS) Boron } \\
\text { ethoxide }\end{array}$ & 1.578 & 73 & 5375199 & Anti-microbial \\
\hline $\begin{array}{l}\text { Butanedioic acid, dimethyl } \\
\text { ester }\end{array}$ & 3.296 & 115 & 2810517 & Flavoring agent \\
\hline $\begin{array}{l}\text { Dodecane, } \\
\text { 2,6,11-trimethyl- }\end{array}$ & 3.773 & 57 & 1598524 & Anti-microbial \\
\hline $\begin{array}{l}\text { 1-Dodecene (CAS) } \\
\text { Adacene } 12\end{array}$ & 6.62 & 55 & 2002846 & Anti-bacterial \\
\hline $\begin{array}{l}\text { Permethylated and reduced } \\
\text { globicide }\end{array}$ & 4.607 & 115 & 896593 & Anti-coagulant \\
\hline $\begin{array}{l}\text { Benzene, } \\
\text { 1,3-bis(1,1-dimethylethyl)- }\end{array}$ & 8.268 & 175 & 5198754 & Adenocarcinoma \\
\hline Benzaldehyde, 4-propyl- & 8.755 & 91 & 1669626 & Biological applications \\
\hline $\begin{array}{l}\text { Dodecane, } \\
\text { 2,6,11-trimethyl- }\end{array}$ & 8.901 & 57 & 922289 & Anti-bacterial \\
\hline 1-Non-adecene (CAS) & 9.808 & 69 & 333589 & Anti-cancer \\
\hline $\begin{array}{l}\text { Hexadecane, } \\
2,6,11,15 \text {-tetramethyl- }\end{array}$ & 10.1 & 57 & 1879178 & Flavoring agent \\
\hline Tetratriacontane (CAS) n- & 12.58 & 57 & 714879 & Anti-cancer \\
\hline Eicosane & 14.43 & 57 & 5924526 & Anti-bacterial \\
\hline $\begin{array}{l}\text { Eicosanoic acid, Arachidic } \\
\text { acid }\end{array}$ & 15.09 & 74 & 1879512 & Anti-oxidant \\
\hline E-14-Hexadecenal & 16.73 & 55 & 6683918 & Anti-inflammatory \\
\hline $\begin{array}{l}\text { Octadecane (CAS) } \\
\text { n-Octadecane }\end{array}$ & 19.42 & 57 & 5421797 & Role in Pheramones \\
\hline $\begin{array}{l}\text { 2- } \\
\text { Butoxysulfonylhexadecane }\end{array}$ & 20.35 & 57 & 1718274 & Anti-microbial \\
\hline E-15-Heptadecenal & 21.17 & 55 & 7676234 & Anti-oxidant \\
\hline $\begin{array}{l}\text { Hexadecanoic acid, } \\
\text { Palmitic acid }\end{array}$ & 23.86 & 74 & 11666977 & Anti-oxidant \\
\hline
\end{tabular}

TPN samples and four selected strains showed non-hemolytic, non-gelatinase, and non-proteolytic activity, indicating that the TPN and micro-organisms present in TPN are non-pathogenic. Results of the presumptive coliform test also revealed the absence of coliforms in the TPN samples.

\section{Evaluation of Probiotic Properties Survival in Acidic pH, Bile, and Simulated Gastric Juice}

The tolerance of isolates to acidic $\mathrm{pH}$ shows their ability to survive in hostile conditions of the gastrointestinal tract. Selected LAB isolates showed maximum survival at $\mathrm{pH} 2.5-3.0$ at $37^{\circ} \mathrm{C}$ for $3 \mathrm{~h}$ (Table 4A). Tolerance to bile salts helps in evaluating the ability of isolates for their establishment in the gastric environment. All 4 isolates showed maximum survival with $0.3 \%$ ox bile after 1 $3 \mathrm{~h}$ of treatment at $37^{\circ} \mathrm{C}$ (Table 4B). All isolates were found to maintain above $95 \%$ viability $(P<0.001)$ at $\mathrm{pH} 3$ and have shown good viable count after $3 \mathrm{~h}$ exposure to $0.3 \%$ bile concentration $(P<0.001)$. Further, all isolates survived well in simulated gastric juice with above $90 \%$ viability after $1-3 \mathrm{~h}$ of incubation at $37^{\circ} \mathrm{C}$. In particular, isolates OUBN3 and OUBN5 showed the highest viability of $8.94 \log \mathrm{cfu} / \mathrm{ml}$ at $3 \mathrm{~h}$ incubation (Table 4C). 
TABLE 2 | Amino acids profile from toddy palm nectar detected by UPLC (ultra-performance liquid chromatography).

\begin{tabular}{|c|c|c|c|}
\hline Name & Conc in $\mu \mathrm{g} / \mathrm{ml}$ & $\%$ mole & Biological importance \\
\hline Histidine & 246.74 & 0.302 & $\begin{array}{l}\text { Protein interactions, Precursor } \\
\text { of histamine }\end{array}$ \\
\hline Aspargine & 242.38 & 0.348 & Protein synthesis \\
\hline Serine & 1566.74 & 2.833 & $\begin{array}{l}\text { Biosynthesis of purines and } \\
\text { pyrimidines }\end{array}$ \\
\hline Arginine & 1275.58 & 1.391 & $\begin{array}{l}\text { Cardiovascular diseases, } \\
\text { anti-aging }\end{array}$ \\
\hline Glycine & 692.69 & 1.754 & $\begin{array}{l}\text { Schizophrenia, } \\
\text { anti-inflammatory }\end{array}$ \\
\hline Aspartic acid & 1248.02 & 1.782 & $\begin{array}{l}\text { Vital role in neuro endocrine } \\
\text { system. }\end{array}$ \\
\hline Citruline & 3214.16 & 3.487 & $\begin{array}{l}\text { Alzheimer's, dementia, Sickle } \\
\text { cell }\end{array}$ \\
\hline Glutamic acid & 2586.01 & 3.341 & Important neurotransmitter \\
\hline Sarcosine & 1351.66 & 2.884 & $\begin{array}{l}\text { Used as adjunctive therapy in } \\
\text { Schizophrenia }\end{array}$ \\
\hline Threonine & 2415.59 & 3.855 & $\begin{array}{l}\text { Immunostimulant, better } \\
\text { livestock growth }\end{array}$ \\
\hline Alanine & 5870.45 & 12.52 & $\begin{array}{l}\text { Treat Hypoglycemia, prostatic } \\
\text { hypertrophy }\end{array}$ \\
\hline GABA & 1722.08 & 3.175 & $\begin{array}{l}\text { Anxiety and improves mood, } \\
\text { PMS }\end{array}$ \\
\hline aAAA & 617.403 & 0.7281 & - \\
\hline bAIBA & 1156.95 & 2.132 & Expression of brown adipocyte \\
\hline Proline & 1165.84 & 1.924 & Proteinogenic \\
\hline OH-Lysine-1 & 1573.41 & 1.844 & Collagen formation \\
\hline OH-Lysine-2 & 10974.76 & 12.86 & Multifunctional enzyme \\
\hline Ornithine & 1253.58 & 1.802 & Reduces stress and fatigue \\
\hline Cystine & 660.55 & 1.036 & Antioxidant and anti-aging \\
\hline Lysine & 3797.71 & 4.937 & $\begin{array}{l}\text { Calcium absorption; } \\
\text { proteinogenic }\end{array}$ \\
\hline Tyrosine & 3489.97 & 3.661 & Stress reliever \\
\hline Methionine & 745.49 & 0.949 & Growth and tissue repair. \\
\hline Valine & 2554.57 & 4.143 & Improves dendritic cell function \\
\hline Leucine & 4202.03 & 6.088 & Growth hormone production \\
\hline Phenylalanine & 2318.24 & 2.667 & $\begin{array}{l}\text { Neuro transmitter, } \\
\text { anti-depressant }\end{array}$ \\
\hline Trptophan & 388.30 & 0.361 & $\begin{array}{l}\text { Sleep aid and psychiatric } \\
\text { disorders }\end{array}$ \\
\hline
\end{tabular}

\section{Auto Aggregation, Hydrophobicity, and Coaggregation}

Isolate OUBN1 has shown higher autoaggregation activity $(81.76 \%)$, while OUBN3 showed the lowest autoaggregation (69.26\%) (Figure 2A). Also, the cell surface hydrophobicity of $79.71 \%$ was observed for OUBN1, which was significantly higher $(p<0.05)$ when compared to OUBN5 (70.15\%). Whereas, there was no significant difference $(p>0.05)$ in cell surface hydrophobicity of LAB isolates OUBN3 and OUBN4 (Figure 2A). All four LAB isolates had good co-aggregation ability with pathogens after $24 \mathrm{~h}$ incubation. Of all these isolates, OUBN1 displayed highest percentage of coaggregation with E. coli MTCC452, K. pneumoniae MTCC109, and S. aureus MTCC902 (Figure 2B).
TABLE 3 | Morphological, biochemical, and physiological characteristics of the $\mathrm{LAB}$ Isolates from Toddy palm nectar.

\begin{tabular}{|c|c|c|c|c|}
\hline Characteristics & OUBN1 & OUBN3 & OUBN4 & OUBN5 \\
\hline Shape & Rod & Cocci & Cocci & Cocci \\
\hline Catalase activity & - & - & - & - \\
\hline Growth in $0.5 \% \mathrm{NaCl}$ & + & + & + & + \\
\hline $1 \% \mathrm{NaCl}$ & + & + & + & + \\
\hline $2 \% \mathrm{NaCl}$ & + & + & + & + \\
\hline $4 \% \mathrm{NaCl}$ & + & + & + & + \\
\hline $6 \% \mathrm{NaCl}$ & + & + & - & + \\
\hline \multicolumn{5}{|l|}{ Growth At } \\
\hline $20^{\circ} \mathrm{C}$ & + & + & + & + \\
\hline $30^{\circ} \mathrm{C}$ & + & + & + & + \\
\hline $37^{\circ} \mathrm{C}$ & + & + & + & + \\
\hline $40^{\circ} \mathrm{C}$ & + & + & + & + \\
\hline $42^{\circ} \mathrm{C}$ & + & + & - & + \\
\hline
\end{tabular}

Positive results (+), Negative results (-).

\section{Antibiotic Sensitivity}

The antibiotic sensitivity of LAB isolates against different antibiotics was determined and obtained results were equated with the interpretative chart of zone size provided in the catalog (Table 5). The four isolates were highly susceptible to antibiotics such as chloramphenicol, tetracycline, penicillinG, clindamycin, erythromycin, rifampicin, and lincomycin; while resistant to trimethoprim, ampicillin, streptomycin, polymyxin-B, vancomycin, gentamycin, amoxicillin, norfloxacin, ciprofloxacin, and kanamycin.

\section{Antimicrobial Activity of LAB Isolates}

The antimicrobial activity of selected LAB isolates against common enteric pathogens was tested. The un-neutralized CFS of all 4 isolates inhibited the growth of all pathogens tested. Whereas, neutralized CFS (nCFS) inhibited the growth of only a few tested pathogens (Table 6). The nCFS of OUBN1 inhibited the growth of $P$. aeruginosa MTCC424 and $P$. vulgaris MTCC426, whereas nCFS of OUBN3 inhibited E. coli MTCC 452, P. aeruginosa MTCC424, E. faecalis MTCC 6845, and K. pneumoniae MTCC 109. It was also observed that nCFS of OUBN5 inhibited the growth of $P$. aeruginosa MTCC424 only while un-neutralized CFS and nCFS of OUBN4 inhibited the growth of all pathogens tested in this study.

\section{DPPH Radical Scavenging and Adhesion Activity}

Radical scavenging activity of LAB isolates ranged from 44.05 to $68.71 \%$ and $\mathrm{IC}_{50}$ was from 75.62 to $117.11 \mu \mathrm{g} / \mathrm{ml}$ (Figure 3). Among the four isolates, OUBN1 showed significantly higher $(p<0.05)$ hydroxyl radical scavenging activity of $68.71 \%$ with an $\mathrm{IC}_{50}$ of $75.62 \mu \mathrm{g} / \mathrm{ml}$, followed by OUBN5 (62.48\%) and OUBN4 (56.59\%) with $\mathrm{IC}_{50}$ of 82.23 and $89.01 \mu \mathrm{g} / \mathrm{ml}$, respectively. Whereas, OUBN3 was found to have lower scavenging activity of $44.05 \%$ with $\mathrm{IC}_{50}$ of $117.11 \mu \mathrm{g} / \mathrm{ml}$ compared to other LAB isolates.

Adhesion assay for four LAB isolates was done for their ability to adhere to HT-29 cell lines and considerable variation was observed as presented in Figure 4. Among all isolates, 


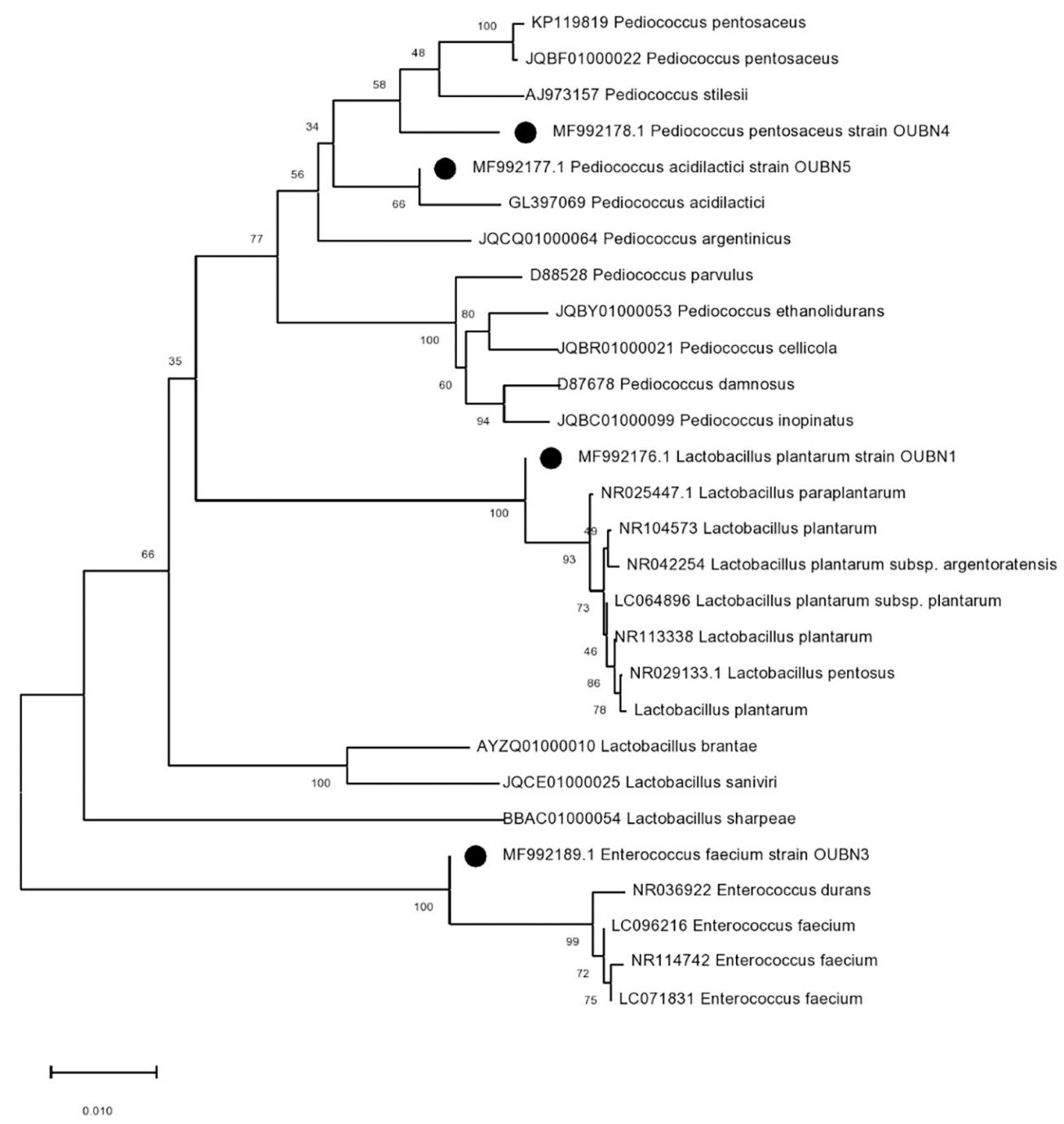

FIGURE 1 | Phylogenetic tree constructed by the neighbour-joining method showing the relative positions of LAB isolates (OUBN1, OUBN3, OUBN4, and OUBN5) based on $16 \mathrm{~S}$ rRNA gene sequences from Palm toddy nectar samples. Evolutionary analyses were conducted in MEGAX. The tree is drawn to scale. The percentage of replicate trees in which the associated taxa are clustered together in the bootstrap test of 1,000 replicates is shown next to the branches.

TABLE 4A | Viable cell count log cfu/ml of LAB survived in MRS broth at different $\mathrm{pH}$ and time intervals.

\begin{tabular}{|c|c|c|c|c|c|c|c|c|}
\hline LAB strains & \multicolumn{4}{|c|}{ pH 2.5} & \multicolumn{4}{|c|}{ pH 3.0} \\
\hline OUBN1 & $7.01 \pm 0.05$ & $6.67 \pm 0.04$ & $6.62 \pm 0.01$ & $6.53 \pm 0.04$ & $6.93 \pm 0.01$ & $6.85 \pm 0.02$ & $6.78 \pm 0.05$ & $6.72 \pm 0.05$ \\
\hline OUBN3 & $6.98 \pm 0.04$ & $6.50 \pm 0.04$ & $6.40 \pm 0.05$ & $6.91 \pm 0.04$ & $6.90 \pm 0.04$ & $6.89 \pm 0.04$ & $6.86 \pm 0.04$ & $6.84 \pm 0.05$ \\
\hline OUBN4 & $7.05 \pm 0.03$ & $6.85 \pm 0.02$ & $6.81 \pm 0.01$ & $6.75 \pm 0.03$ & $6.96 \pm 0.03$ & $6.90 \pm 0.05$ & $6.85 \pm 0.04$ & $6.89 \pm 0.02$ \\
\hline OUBN5 & $7.03 \pm 0.03$ & $6.59 \pm 0.03$ & $6.56 \pm 0.02$ & $6.51 \pm 0.02$ & $6.99 \pm 0.03$ & $6.96 \pm 0.03$ & $6.88 \pm 0.03$ & $6.94 \pm 0.02$ \\
\hline
\end{tabular}

The mean of three values is presented $\pm S D$ for each sample. Viable counts were expressed in log10 cfu/ml. P-value is significant $(P<0.001)$.

OUBN1 and OUBN5 showed strong adhesion, while OUBN3 and OUBN4 were moderate.

\section{Anticancer Activity and Cell Apoptosis}

The CFS of four LAB isolates were tested for their anti-cancer activity against HT-29 cells. Though all four isolates exhibited anti-cancer activity after treatment of cells with $100 \mu \mathrm{l} / \mathrm{ml}$ CFS in contrast to untreated cells, the highest anti-cancer activity of $88.55 \%$ was found with isolate OUBN1 while the least activity of $64.05 \%$ was found with OUBN3 (Figure 5A).

Subsequently, staining with DAPI was done to detect the visual indication of cell death in untreated and treated cells 
TABLE 4B | Viable cell count log cfu/ml of LAB survived in MRS after $0,1,3$, and $4 \mathrm{~h}$ in the presence of $0.3 \%$ bile salts.

\begin{tabular}{lccccc}
\hline \multicolumn{5}{c}{ Viable cell count log cfu/ml } \\
\cline { 2 - 6 } $\begin{array}{l}\text { LAB } \\
\text { strains }\end{array}$ & $\mathbf{0} \mathbf{h}$ & $\mathbf{1} \mathbf{h}$ & $\mathbf{2} \mathbf{h}$ & $\mathbf{3} \mathbf{~}$ & $\mathbf{4} \mathbf{~ h}$ \\
\hline OUBN1 & $7.90 \pm 0.03$ & $7.67 \pm 0.05$ & $7.78 \pm 0.05$ & $7.84 \pm 0.05$ & $7.85 \pm 0.03$ \\
OUBN3 & $8.04 \pm 0.01$ & $7.71 \pm 0.06$ & $7.69 \pm 0.07$ & $7.82 \pm 0.03$ & $7.81 \pm 0.03$ \\
OUBN4 & $7.99 \pm 0.03$ & $7.72 \pm 0.04$ & $7.84 \pm 0.03$ & $7.90 \pm 0.02$ & $7.87 \pm 0.04$ \\
OUBN5 & $8.01 \pm 0.03$ & $7.71 \pm 0.03$ & $7.85 \pm 0.08$ & $7.98 \pm 0.03$ & $7.92 \pm 0.03$ \\
\hline $\begin{array}{l}\text { The mean of three values is represented as } \pm \text { SD for each sample. Viable counts } \\
\text { were expressed in log10 cfu/ml. P-value is highly significant }(P<0.0001) .\end{array}$
\end{tabular}

TABLE 4C | Viable cell count log cfu/ml of LAB survived in simulated gastric juice at different time intervals.

\begin{tabular}{lcccc}
\hline & \multicolumn{4}{c}{ Viable cell count log cfu/ml } \\
\cline { 2 - 5 } LAB & $\mathbf{0 ~ h}$ & $\mathbf{1} \mathbf{~}$ & $\mathbf{2} \mathbf{~}$ & $\mathbf{3} \mathbf{~ h}$ \\
strains & & & & \\
\hline OUBN1 & $6.96 \pm 0.05$ & $6.89 \pm 0.04$ & $6.88 \pm 0.03$ & $6.82 \pm 0.03$ \\
OUBN3 & $9.00 \pm 0.02$ & $8.94 \pm 0.03$ & $8.95 \pm 0.02$ & $8.94 \pm 0.02$ \\
OUBN4 & $7.98 \pm 0.01$ & $7.94 \pm 0.02$ & $7.91 \pm 0.06$ & $7.90 \pm 0.03$ \\
OUBN5 & $9.01 \pm 0.03$ & $8.93 \pm 0.03$ & $8.92 \pm 0.05$ & $8.94 \pm 0.03$ \\
\hline
\end{tabular}

The mean of three values is presented for each sample $\pm S D$. Viable counts wer expressed in log cfu/ml. No significant $(P<0.17)$ difference in the viability of the cells in the gastric conditions incubated for $3 \mathrm{~h}$.

by fluorescent microscopy. Viable cells were observed to be blue intact, while dead cells were differentiated by bright blue with shrinking and blubbing along with condensed nucleus or fragments that ultimately degenerated, as shown by arrows in Figure 5B.

\section{DISCUSSION}

In the present study, a naturally fermented and easily available drink, toddy palm nectar (TPN) was selected to evaluate its nutritional value and probiotic attributes.

Among the volatile fatty acids (VFA) in such natural ferments, alcohols are the main components and are considered the final standard products of degradation of glucose and amino acid catabolism. Of all VFAs, N-hexadecanoic acid is the major one found in TPN, which is an anti-inflammatory compound and also a phospholipase A2 inhibitor. Hydrolysis of ester bond linkages by phospholipase A2 is the initiating step to start inflammation. Enzyme kinetics study proved that n-hexadecanoic acid inhibits phospholipase A2 in a competitive way (Aparna et al., 2012). Other fatty acids identified include hexadecanoic acid methyl ester (CAS), methyl palmitate, and E15-heptadecenal, which are responsible for the antibacterial and antioxidant properties of TPN. Several other volatile compounds have been reported previously from different types of palm wines such as Cocas nucifera (Borse et al., 2007; Karthikeyan et al., 2014) Nypa fruticans (Nur Aimi et al., 2013), and Elaeis guineensis (Lasekan and Abbas, 2010). Identification of octadecanoic acid in Lactobacillus helveticus by GC-MS was reported by Sharma et al. (2014). Various organic acids and effective antimicrobial activity of Lactobacillus strains further supported the organic acid-mediated inhibitory effect (Bajpai et al., 2016). The use of medicinal oils rich in n-hexadecanoic acid for the treatment of rheumatic complications has been described in the traditional

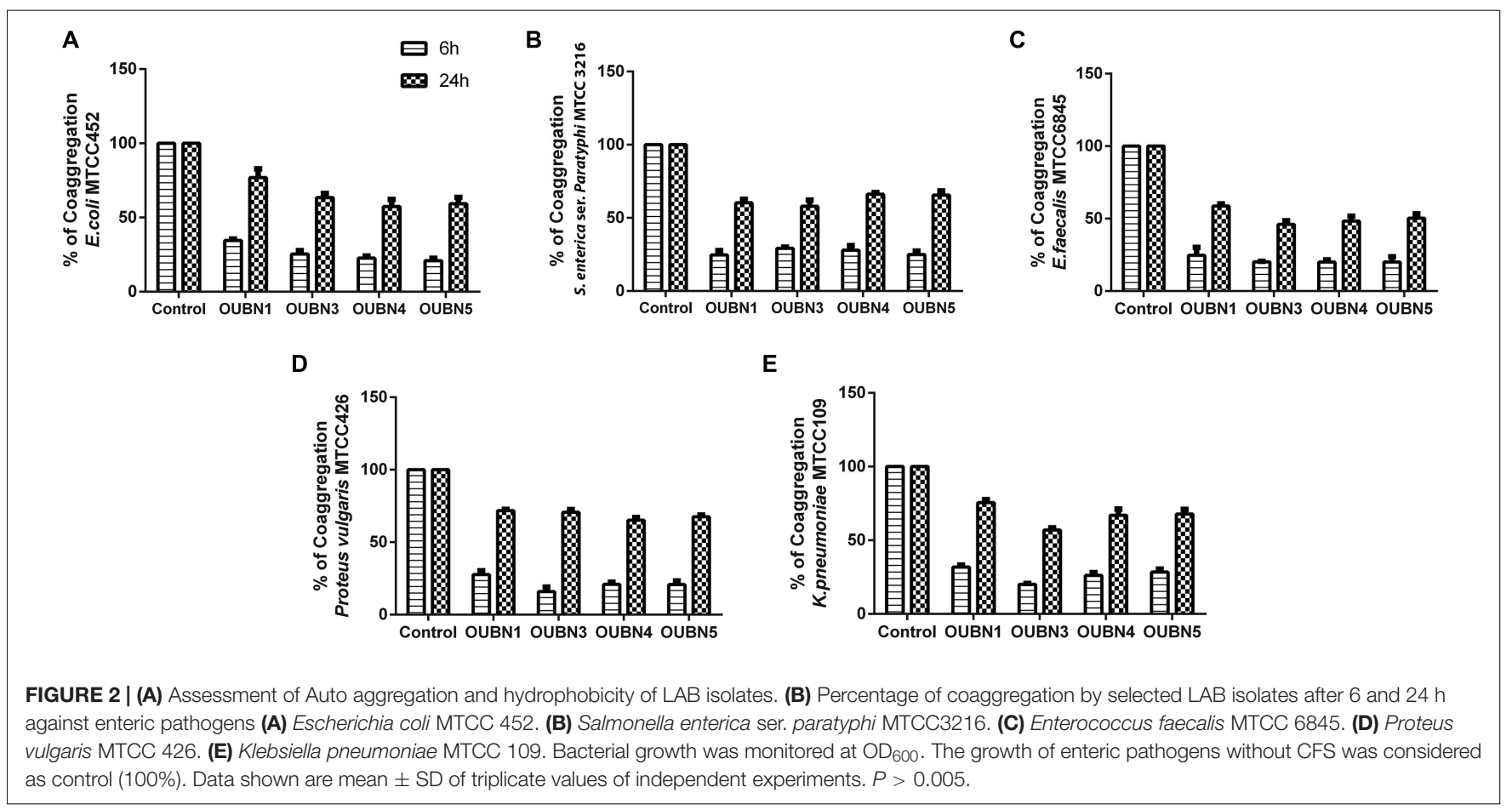


medical system of Indian Ayurveda (Aparna et al., 2012). Previous studies confirm the anti-microbial and anti-oxidant properties exerted by the presence of organic acids in fermented foods (Bajpai et al., 2016).

In the present study, 26 amino acids were identified by UPLC, possibly of plant origin, but there is a possibility that microorganisms may also contribute to amino acid production. $\mathrm{OH}-$ lysine-2 is an essential amino acid and is found to be

TABLE 5 | Antibiotic susceptibility of LAB strains isolated from toddy palm nectar samples.

\begin{tabular}{lcccc}
\hline & \multicolumn{4}{c}{ ZOI in mm } \\
\cline { 2 - 5 } Antibiotics & OUBN1 & OUBN3 & OUBN4 & OUBN5 \\
\hline Trimethoprim $(10 \mu \mathrm{g})$ & - & - & + & + \\
Ampicillin $(10 \mu \mathrm{g})$ & - & - & - & - \\
Streptomycin $(10 \mu \mathrm{g})$ & - & - & - & - \\
Chloramphenicol $(30 \mu \mathrm{g})$ & +++ & ++++ & +++ & ++++ \\
Polymyxin-B $(300 \mathrm{units})$ & - & - & - & - \\
Tetracycline $(30 \mu \mathrm{g})$ & ++++ & ++++ & ++++ & ++++ \\
Penicillin-G $(10 \mathrm{units})$ & +++ & +++ & +++ & +++ \\
Vancomycin $(30 \mu \mathrm{g})$ & - & - & - & - \\
Clindamycin $(2 \mu \mathrm{g})$ & ++++ & ++++ & ++++ & ++++ \\
Gentamycin $(10 \mu \mathrm{g})$ & + & + & - & - \\
Amoxycillin $(10 \mu \mathrm{g})$ & + & - & + & + \\
Erythromycin $(15 \mu \mathrm{g})$ & +++ & ++++ & ++++ & \\
Rifampicin $(5 \mu \mathrm{g})$ & ++++ & ++++ & ++++ & ++++ \\
Norfloxacin $(10 \mu \mathrm{g})$ & - & - & - & - \\
Ciprofloxacin $(5 \mu \mathrm{g})$ & - & - & - & - \\
Lincomycin $(10 \mu \mathrm{g})$ & ++ & +++ & +++ & +++ \\
Kanamycin $(30 \mu \mathrm{g})$ & - & - & - & - \\
\hline ZOI & & & + & + \\
\hline
\end{tabular}

ZOI (zone of inhibition) - no effect detected,,,,++++++++++ represents diameter of zone of inhibition between 1-2, 2-5, 5-10 and more than $10 \mathrm{~mm}$, respectively.

TABLE 6 | Antimicrobial activity against enteric pathogens shown by LAB isolated from toddy palm nectar samples

\begin{tabular}{|c|c|c|c|c|c|c|c|c|}
\hline \multirow[t]{3}{*}{ Pathogens } & \multicolumn{8}{|c|}{ Zone of inhibition in $\mathrm{cm}$} \\
\hline & \multicolumn{2}{|c|}{ OUBN1 } & \multicolumn{2}{|c|}{ OUBN3 } & \multicolumn{2}{|c|}{ OUBN4 } & \multicolumn{2}{|c|}{ OUBN5 } \\
\hline & CFS & nCFS & CFS & nCFS & CFS & nCFS & CFS & nCFS \\
\hline $\begin{array}{l}\text { E. coli MTCC } \\
452\end{array}$ & 1.8 & - & 1.6 & 1.2 & 1.6 & 1.4 & 1.8 & - \\
\hline $\begin{array}{l}P . \text { aeruginosa } \\
\text { MTCC424 }\end{array}$ & 1.8 & 1.0 & 1.6 & 1.0 & 1.8 & 1.0 & 1.8 & 1.2 \\
\hline $\begin{array}{l}\text { P. vulgaris } \\
\text { MTCC426 }\end{array}$ & 1.6 & 0.6 & 1.8 & - & 1.6 & 0.6 & 1.6 & - \\
\hline $\begin{array}{l}\text { S. para typhi } \\
\text { enterica ser. } \\
\text { MTCC } 3216\end{array}$ & 1.4 & - & 1.4 & - & 1.4 & 0.6 & 1.6 & - \\
\hline $\begin{array}{l}\text { E. faecalis } \\
\text { MTCC } 6845\end{array}$ & 1.6 & 1.6 & 1.6 & 1.6 & 1.8 & 1.2 & 1.6 & - \\
\hline $\begin{array}{l}\text { K. pneumoniae } \\
\text { MTCC } 109\end{array}$ & 2.0 & 1.6 & 2.0 & 1.8 & 2.4 & 1.8 & 2.0 & - \\
\hline
\end{tabular}

CFS (Cell-free supernatant), nCFS (Neutralized cell-free supernatant).

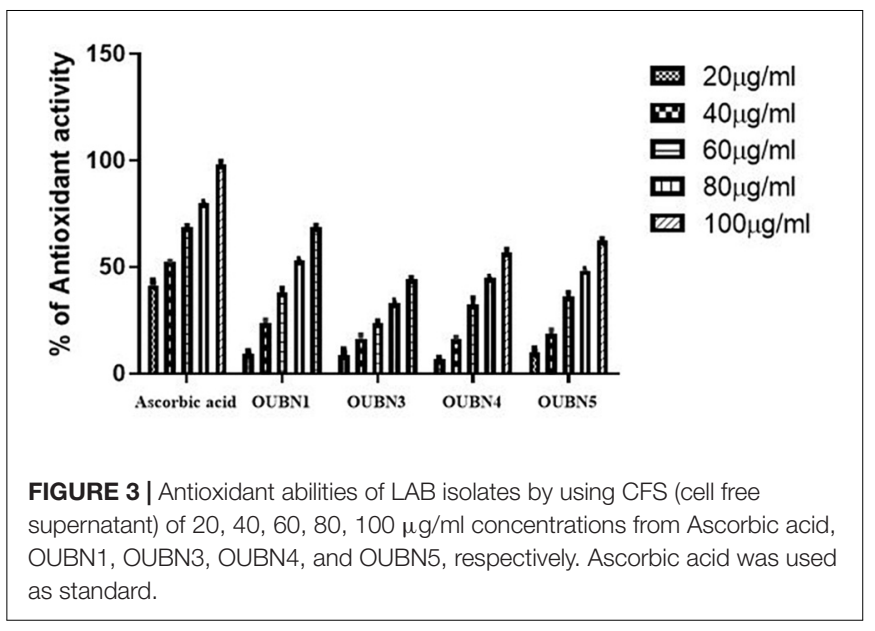

the primary amino acid in TPN. It plays a vital role in various biological processes, including the conversion of lipids into metabolic energy, synthesis of collagen fibers, connective tissues, and also participates in the regulation of calcium levels (Peter et al., 2010). Alanine was found as the second major amino acid in TPN tested. Alanine is involved in the metabolism of sugars and acids, which is known to boost immunity and provide energy to the brain, central nervous system, and muscle tissue (Sarah et al., 2013). Leucine was the third major amino acid, essential in protein metabolism, and plays a role in the initiation pathways of muscle protein synthesis. Alanine participates in reversible phosphorylation of proteins that control the binding of mRNA to the 40S ribosomal subunit (Li et al., 2011). GABA ( $\gamma$-aminobutyric acid) is another important compound found in TPN which is an inhibitory neurotransmitter of the central nervous system. Production of GABA by $L$. fermentum isolated from palm wine was reported by Rayavarapu et al. (2019). Citrulline is also found in TPN and it is the primary precursor of L-arginine in the nitric oxide cycle. Citrulline is known to prevent neuronal cell death and protect against cerebrovascular damage. Therefore, it may provide a neuroprotective role to improve cerebrovascular dysfunction (Lee and Kang, 2018).

Of 26 samples, 120 morphologically different LAB were identified based on differential growth and in vitro probiotic characteristics. Previous studies have specified the presence of various $\mathrm{LAB}$, non-LAB, and yeast in palm wine (Tapsoba et al., 2016; Astudillo-Melgar et al., 2019). In our preliminary studies, it was observed that $\mathrm{LAB}$ were more abundant than non-LAB and yeasts in TPN. One of our previous studies reported the functional probiotic and therapeutic potential of Saccharomyces cerevisiae, which was isolated from palm nectar (Srinivas et al., 2017). Tolerance of selected LAB isolates to various salinity and temperature ranges show that these $\mathrm{LAB}$ can endure growing in severe unfavorable environments which is an optimistic feature to select a probiotic.

Based on the above observations, four potential bacterial isolates were selected and subjected to 16S rRNA analysis, confirmed as LAB at the species level, and named as Lactobacillus 

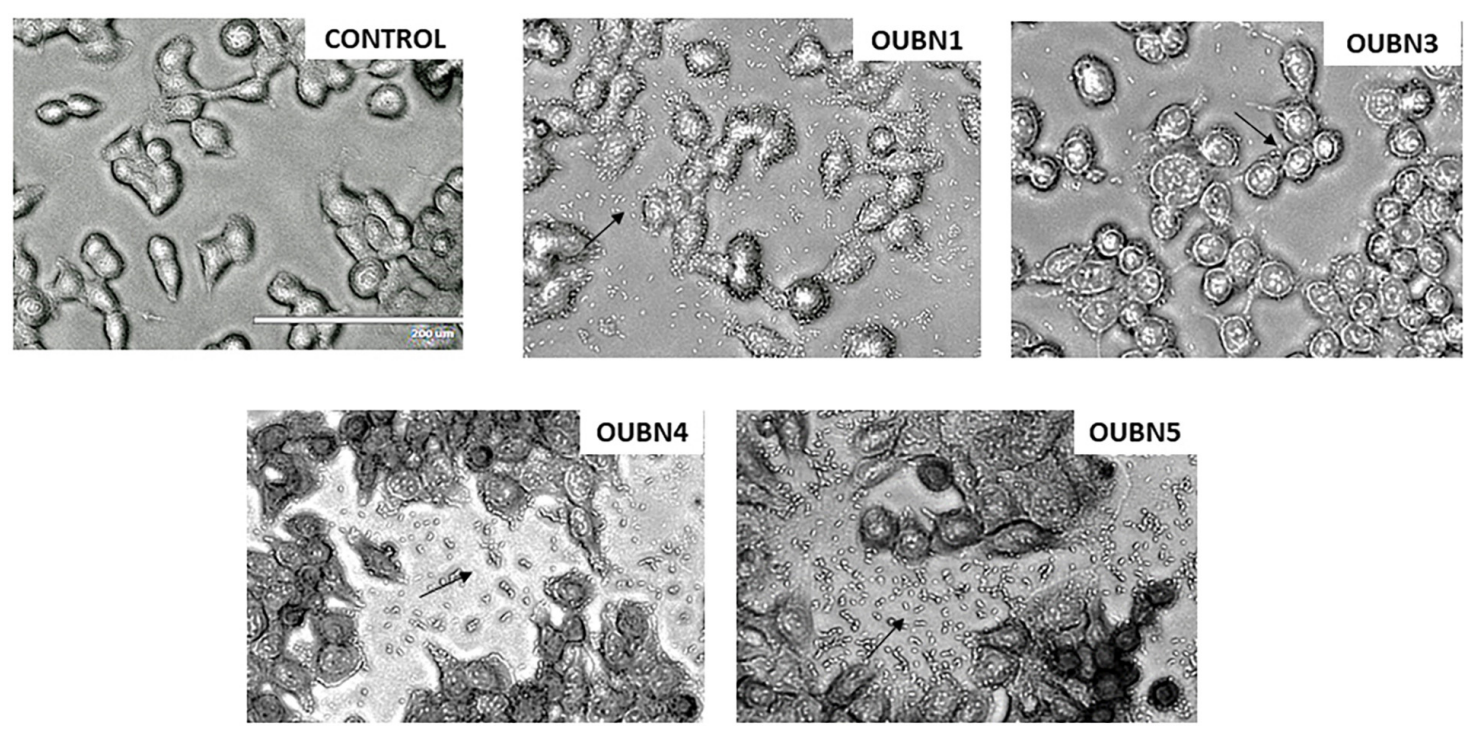

FIGURE 4 | Adhesion of LAB strains on HT-29 cell cultures observed under oil immersion microscope (100X) after staining with Giemsa strain. (Control)- HT-29 cell line without treatment and HT-29 cells treatment with OUBN1, OUBN3, OUBN4, OUBN5, respectively. Scale $200 \mu \mathrm{m}$.

plantarum group OUBN1, Enterococcus faecium OUBN3, Pediococcus acidilactici OUBN4, and Pediococcus pentosaceous OUBN5. The 16S rRNA analysis revealed high efficacy and congruency for LAB species and selected LAB isolates may be candidates for further investigation as better probiotic strains.

The evaluation of hemolytic activity is regarded as a safety asset according to the European Food Safety Authority (EFSA), to consider the probiotic strains (Joint FAO/WHO Expert Committee on Food Additives Meeting and World Health Organization, 2006). Hemolytic activity of selected strains was evaluated on Columbia blood agar plates and the tested strains showed neither $\alpha$ - hemolytic nor $\beta$-hemolytic activity. Our findings were in agreement with the results of $\mathrm{Oh}$ and Jung (2015) and Wang et al. (2018), who evaluated the Lactobacillus species isolated from millet-based alcoholic beverages fermented by traditional methods and spontaneously fermented non-dairy foodstuffs for their hemolytic activity. Non-hemolytic activity is noteworthy during the selection of probiotic strains, as such strains are non-virulent and lack of hemolysin ensures their non-pathogenic nature (Joint FAO/WHO Expert Committee on Food Additives Meeting and World Health Organization, 2006). Gelatinase enzyme is considered a virulence factor as it may hydrolyze collagens that initiate an inflammatory response (Da Silva et al., 2019). However, in the present investigation, all the LAB were non-hemolytic and non-gelatinolytic. Nonhemolytic and non-gelatinase criterion is measured to be significant to use as starter cultures in the dairy industry (Marroki and Bousmaha-Marroki, 2014). None of the LAB of the present study is positive for proteolytic activity. No pathogenic organisms were detected in any of the toddy (TPN) samples studied, indicating the hygienic status of the tappers, the extraction method involved and the materials used. Results of, non-hemolytic, non-gelatinase, non-proteolytic properties, absence of coliforms, mild ethanol content of TPN indicate its microbiological safe nature.

Tolerance to low $\mathrm{pH}$ and high concentration of bile salts is one of the prerequisites for characterizing probiotic strains. Also, they should effectively pass through the gastric stomach and also remain in the small intestine (Anandharaj et al., 2015). Ilavenil et al. (2016) studied four LAB strains and reported a low $\mathrm{pH}(2.5)$ and bile salts $(0.3 \%)$ tolerance, reflecting high survival and proliferation efficiency in hostile intestinal conditions. In our study, exposure to $\mathrm{pH} 2.5$ dramatically reduced the count of different $\mathrm{LAB}$ isolates after $2 \mathrm{~h}$ of incubation, while efficient growth was observed after $3 \mathrm{~h}$ of exposure to $\mathrm{pH}$ 3.0. Overall, no significant reduction in CFU count was observed after exposure to $\mathrm{pH}$ 3.0. This may be due to a sudden drop in optimal $\mathrm{pH}$ and subsequent adaptation to harsh acidic conditions, which has been observed with a higher survival rate in our LAB isolates. Tolerance to $0.3 \%$ bile salts was a positive observation with selected LAB isolates which promote easy colonization to the host gut as previously described (Adesulu-Dahunsi et al., 2018). Few studies reported high survival rates of selected $\mathrm{LAB}$ strains at $\mathrm{pH}$ 2.5 and $0.3 \%(\mathrm{w} / \mathrm{v})$ bile salts (Nami et al., 2019). Growth of $\mathrm{LAB}$ isolates has also been observed in the simulated gastric juice to assess their survival in hostile environments of the gastrointestinal tract. Isolates were able to resist simulated digestive tract conditions with a slight reduction in the number of viable cells, and these results are in agreement with previous findings of Nami et al. (2019).

After entering the intestine, probiotics must adhere to the intestinal mucosa, which accelerates the transient colonization and hinders its elimination by peristalsis. The current study showed a high auto-aggregation of selected LAB isolates, which is in agreement with observations of Somashekaraiah et al. (2019). 

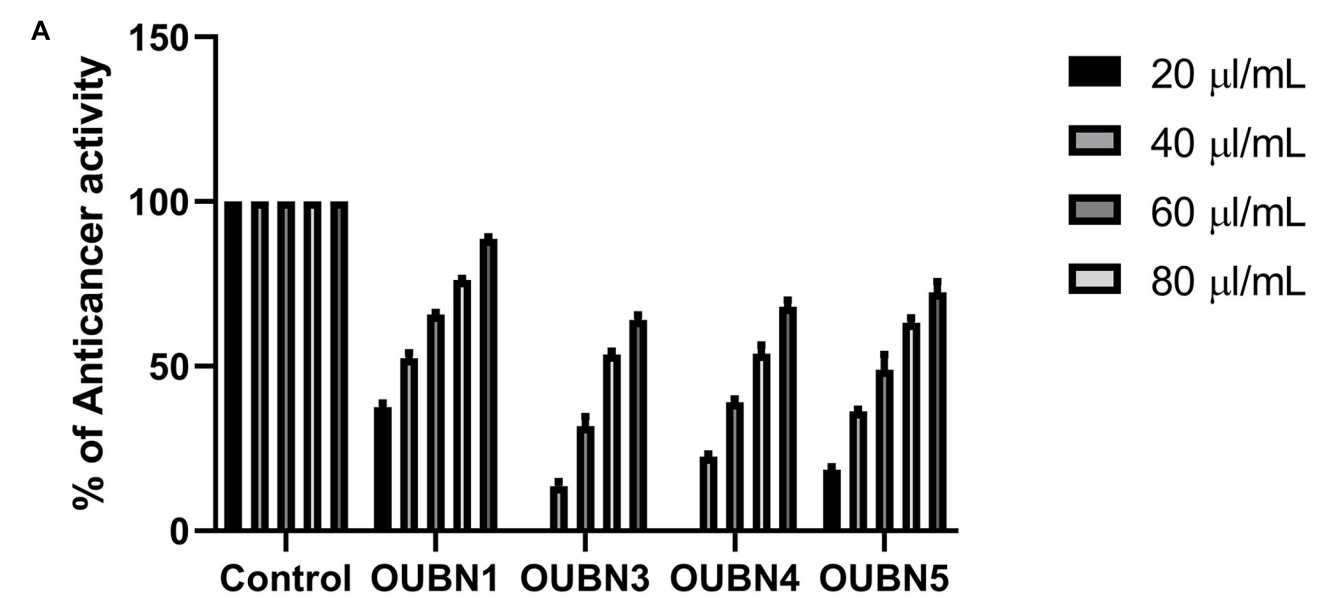

B
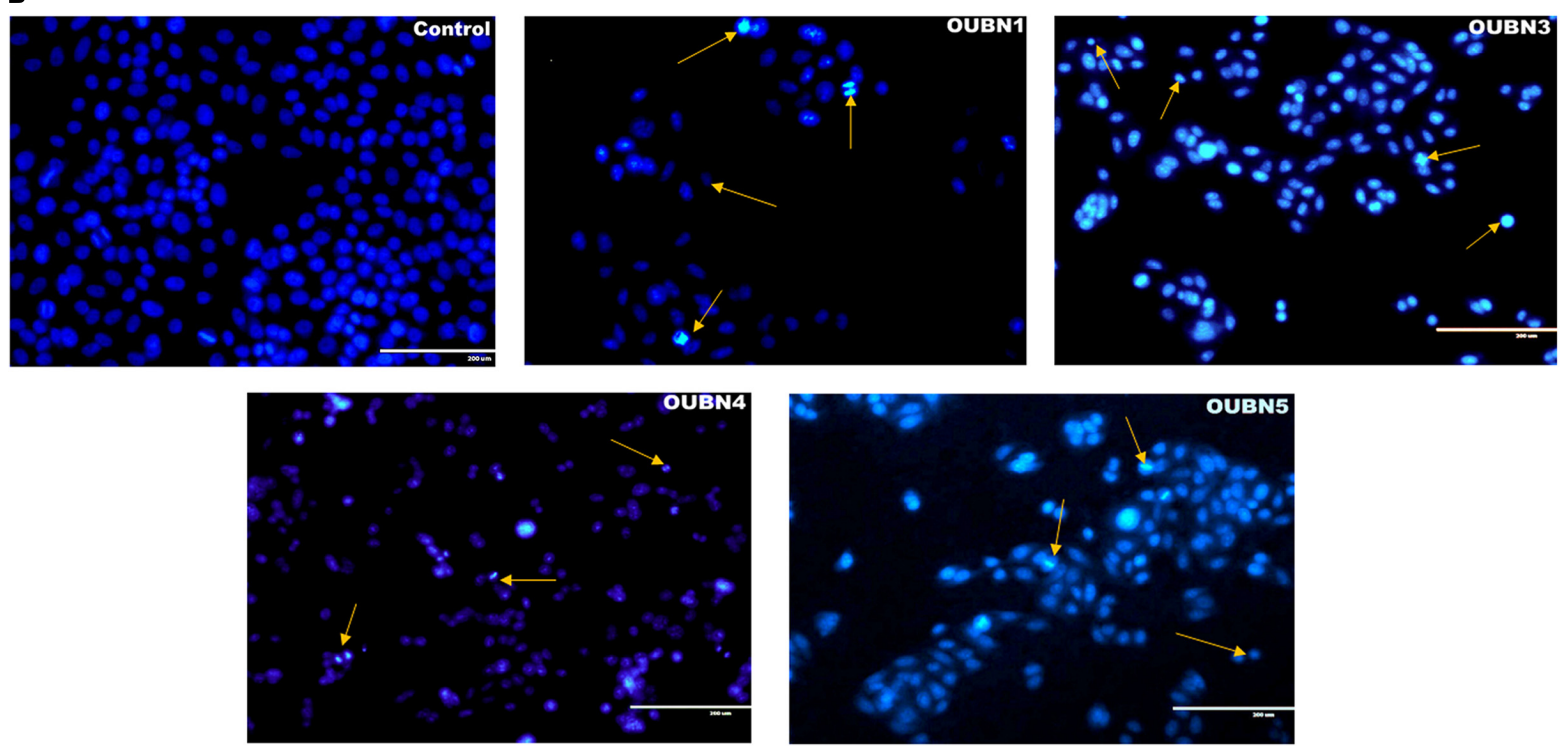

FIGURE 5 | (A) Anticancer activity determined by MTT [-(4, 5-Dimethylthiazol-2-yl)-2, 5-diphenyltetrazolium bromide] assay. Experiments were done by using CFS of $20,40,60,80,100 \mu \mathrm{l} / \mathrm{ml}$ concentrations from CFS of OUBN1, OUBN3, OUBN4, and OUBN5, respectively. Data shown are triplicate values of mean \pm SD of independent experiments. (B) Apoptosis determined for untreated and treated HT-29 cells with OUBN1, OUBN3, OUBN4, OUBN5 isolates by DAPI (4,

6-diamidino-2-phenylindole) staining. Scale $200 \mu \mathrm{m}$.

There is a strong association between auto-aggregation of probiotic strains and their ability to adhere to intestinal epithelial cells, signifying host defense, which is a prerequisite for effective colonization and better persistence in the gastrointestinal tract (Zommiti et al., 2018). Cell surface hydrophobicity has been carried out to determine the efficiency of strains to adhere to the gut region since it is one of the characteristic features of potential probiotic strains. In the present study, four isolates exhibited hydrophobicity greater than $70 \%$ and interestingly, strain OUBN1 showed the highest of $79.71 \%$. The auto-aggregation and adhesion efficiency of our isolates are superior to the LAB strains isolated from plant-based fermented food and neera (Choi et al., 2018; Somashekaraiah et al., 2019). Co-aggregation ability of the strains could be a key factor, potentially inhibiting the adherence of pathogenic bacteria to the epithelial surface, which leads to hampering of surface colonization by pathogens. The Autoaggregation ability of LAB plays a vital role in adhesion to intestinal epithelial cells and thus further prevents the colonization of pathogens. Among the strains, OUBN1 exhibited a maximum coaggregation of $>70 \%$ with E. coli MTCC452, K. pneumoniae MTCC109, and S. aureus MTCC902. The inhibitory impact of LAB strains can be associated with the co-aggregation of foodborne pathogenic bacteria. Since the autoaggregation potential of LAB strains plays an important role in adhesion to intestinal epithelial cells, they further prevent the colonization of pathogens (Yadav et al., 2016). These results proved that the $\mathrm{LAB}$ strains assessed in the current study could tolerate and survive efficiently in the human intestinal environment. 
To be accepted as an excellent probiotic, organisms must meet specific functional properties like sensitivity to antibiotics and antimicrobial activity against pathogens. The inherent resistance of LAB strains to antibiotics is not considered a risk to human and animal health but may promote therapeutic and preventive benefits when administered together with antibiotics (Al Kassaa et al., 2014). In our study, four LAB isolates were tested for sensitivity to 17 different types of antibiotics and found that they are susceptible to a specific group of antibiotics, ampicillin, erythromycin, chloramphenicol, and tetracycline. Present results are in agreement with the previous study by Caggia et al. (2015) who isolated LAB from kimchi and found it susceptible to penicillin G, erythromycin, and clindamycin which bind to ribosomes, further block protein synthesis, and are effective against Gram-positive microorganisms (Reuben et al., 2020). The LAB isolates of the present study showed resistance to aminoglycosides (gentamicin and streptomycin) sulfonamide (trimethoprim) and glycopeptide (vancomycin) has been reported in $\mathrm{LAB}$, which is associated with its intrinsic resistance resulting from the permeability of its membrane, probably through a resistance flow mechanism that is not transferable (Gueimonde et al., 2013). Furthermore, the electron transport mediated by cytochrome responsible for the absorption of the drug is absent in most of the LAB (Monteagudo-Mera et al., 2012). The intrinsic resistance of LAB strains to antibiotics is not considered a risk to animal and human health but may promote therapeutic and preventive benefits when administered together with antibiotics (Al Kassaa et al., 2014). Natural resistance to ciprofloxacin has been observed in our study, which is consistent with the study conducted by Tang et al. (2018). Geographic location and source of LAB also determined the antibiotic susceptibility patterns of potential probiotic strains (Anandharaj et al., 2015). Antibiotic resistance of bacteria has progressively become an alarming medical problem. Multiple-drug resistance of pathogenic microorganisms against prophylactic antibiotics has become a risk and serious challenge to overcome with the purpose to treat infected persons. Therefore, susceptibility to antibiotics signifies a fundamental prerequisite for probiotics.

Antagonistic activity and production of antimicrobial compounds by LAB against enteric pathogens can be considered as the main probiotic attribute for maintaining the stability of intestinal microbiota. Previous studies have examined the role of LAB and their inhibition of various enteric and foodborne pathogens ( $\mathrm{Li}$ et al., 2017; Reuben et al., 2020). In our experiments, un-neutralized CFS of LAB showed significant antagonism against applied enteric pathogens. This could be due to the activities of organic acids they produce (Choi et al., 2018). Various effects of nCFS on inhibition of pathogens suggesting the production of bacteriocins by LAB could play a crucial role in the abolition of potentially harmful gut microbes. The LAB strains also contribute to the quality improvement of fermented foods, through deterioration and control of pathogenic bacteria, thus extending the shelf life and improving sensory quality (Beganović et al., 2014).

Fermented palm nectar contains various phytochemicals and microorganisms, including LAB, which exhibit antioxidant activity (Ghosh et al., 2015). The DPPH assay should be considered as an easy and cost-effective spectrophotometric method to evaluate the antioxidant activity of natural compounds and fermented food products. In the present study, LAB isolates showed the dose-dependent scavenging potential of DPPH as the percentage of scavenging activity increased linearly in all samples with increased concentration of DPPH and the reported $\mathrm{IC}_{50}$ values suggested a defensive role of TPN against oxidative stress with favorable radical quenching activities. Strains OUBN1 and OUBN5 showed higher antioxidant activity compared to previous studies by Lin et al. (2018), who reported antioxidant activity of L. plantarum AR501 and P. pentosaceus AR243.

HT-29 cell lines were used to assess the adhesion ability and anti-cancer activity of LAB isolates. L. plantarum group OUBN1 and $P$. pentosaceous OUBN5 showed excellent adhesive properties. MTT assay is the most widely used technique for examining new components in a short period based on their level of toxicity to cancer cells (Vuotto et al., 2014). Srinivas et al. (2017) evaluated the cytotoxic effect of yeast isolates OBS1 and OBS2 using cancer cell lines MCF7 (breast cancer) and IMR32 (neuroblastoma). Apoptosis was observed by fluorescent microscopy, which is considered a primary strategy during chemotherapy of cancer. DAPI staining method was used to observe visual symptoms of apoptosis in treated cells. Viable cells were identified as intact blue cells, while apoptotic cells were characterized by morphological changes, such as blue cells contracted with a fragmented or condensed nucleus (Haghshenas et al., 2015). HT-29 cells treated with LAB strains for $48 \mathrm{~h}$ showed symptoms of apoptosis, including membrane blisters, cell narrowing, nucleus fragmentation, and apoptotic body formation (Elliott et al., 2007). In the present study, CFS of all four LAB isolates showed significant cell morphological changes, including cell contraction, damage, and degeneration of cells.

\section{CONCLUSION}

The present investigation involves the nutritional profiling and isolation of lactic acid bacterial strains from TPN. The nutritional profile of TPN confirmed the presence of 18 VFAs and 26 amino acids. Due to the presence of probiotic microbiota, with rich amino acid and volatile fatty acid profile, TPN the natural drink can be tried as a therapeutic agent. All the four LAB isolates viz. L. plantarum group OUBN1, E. faecium OUBN3, $P$. acidilactici OUBN4, and $P$. pentosaceous OUBN5 were found to be efficiently tolerant of low $\mathrm{pH}$ and bile conditions along with other severe intestinal parameters of the stomach. All four isolates showed good antimicrobial activity along with considerable antioxidant and anti-cancer activities. These strains exhibited ideal surface-binding properties, which are useful in colonizing the gastrointestinal tract and play a significant role in increasing healthy gut microbiota. The Lactobacillus plantarum group (reclassified as Lactiplantibacillus plantarum) OUBN1 and Pediococcus pentosaceous OUBN5 expressed potential probiotic characteristics. In conclusion, the LAB isolates from TPN established a probiotic attribute in vitro, thus revealing the ability to employ them as possible probiotic microbiota in food preparations. 


\section{DATA AVAILABILITY STATEMENT}

The datasets presented in this study can be found in online repositories. The names of the repository/repositories and accession number(s) can be found in the article/ Supplementary material.

\section{AUTHOR CONTRIBUTIONS}

All the experiments were carried out by NP with the help of $\mathrm{KB}$. RL and $\mathrm{BB}$ designed the concept, monitored the work,

\section{REFERENCES}

Adesulu-Dahunsi, A. T., Jeyaram, K., and Sanni, A. I. (2018). Probiotic and technological properties of exopolysaccharide producing lactic acid bacteria isolated from cereal-based nigerian fermented food products. Food Control 92, 225-231. doi: 10.1016/j.foodcont.2018.04.062

Al Kassaa, I., Hamze, M., Hober, D., Chihib, N.-E., and Drider, D. (2014). Identification of vaginal lactobacilli with potential probiotic properties isolated from women in North Lebanon. Microb. Ecol. 67, 722-734. doi: 10.1007/ s00248-014-0384-7

Altschul, S. F., Madden, T. L., Schäffer, A. A., Zhang, J., Zhang, Z., Miller, W., et al. (1997). Gapped BLAST and PSI-BLAST: a new generation of protein database search programs. Nucleic Acids Res. 25, 3389-3402. doi: 10.1093/nar/25.17.3389

Amoa-Awua, W. K., Sampson, E., and Tano-Debrah, K. (2007). Growth of yeasts, lactic and acetic acid bacteria in palm wine during tapping and fermentation from felled oil palm (Elaeis guineensis) in Ghana. J. Appl. Microbiol. 102, 599-606. doi: 10.1111/j.1365-2672.2006.03074.x

Anandharaj, M., Sivasankari, B., Santhanakaruppu, R., Manimaran, M., Rani, R. P., and Sivakumar, S. (2015). Determining the probiotic potential of cholesterolreducing Lactobacillus and Weissella strains isolated from gherkins (fermented cucumber) and south Indian fermented koozh. Res. Microbiol. 166, 428-439. doi: 10.1016/j.resmic.2015.03.002

Aparna, V., Dileep, K. V., Mandal, P. K., Karthe, P., Sadasivan, C., and Haridas, M. (2012). Anti-inflammatory property of n-hexadecanoic acid: structural evidence and kinetic assessment. Chem. Biol. Drug Des. 80, 434-439. doi: 10. 1111/j.1747-0285.2012.01418.x

Aslam, H., Green, J., Jacka, F. N., Collier, F., Berk, M., Pasco, J., et al. (2020). Fermented foods, the gut and mental health: a mechanistic overview with implications for depression and anxiety. Nutr. Neurosci. 23, 659-671. doi: 10. 1080/1028415X.2018.1544332

Aspri, M., Papademas, P., and Tsaltas, D. (2020). Review on non-dairy probiotics and their use in non-dairy based products. Fermentation 6:30. doi: 10.3390/ fermentation 6010030

Astudillo-Melgar, F., Ochoa-Leyva, A., Utrilla, J., and Huerta-Beristain, G. (2019). Bacterial diversity and population dynamics during the fermentation of palm wine from Guerrero Mexico. Front. Microbiol. 10:531. doi: 10.3389/fmicb.2019. 00531

Bajpai, V. K., Han, J.-H., Rather, I. A., Park, C., Lim, J., Paek, W. K., et al. (2016). Characterization and antibacterial potential of lactic acid bacterium Pediococcus pentosaceus 4I1 isolated from freshwater fish Zacco koreanus. Front. Microbiol. 7:2037. doi: 10.3389/fmicb.2016.02037

Barigela, A., and Bhukya, B. (2021). Probiotic Pediococcus acidilactici strain from tomato pickle displays anti-cancer activity and alleviates gut inflammation in-vitro. 3 Biotech 11:23.

Bartkiene, E., Zavistanaviciute, P., Lele, V., Ruzauskas, M., Bartkevics, V., Bernatoniene, J., et al. (2018). Lactobacillus plantarum LUHS135 and paracasei LUHS244 as functional starter cultures for the food fermentation industry: characterisation, mycotoxin-reducing properties, optimisation of biomass growth and sustainable encapsulation by using dairy by-products. LWT 93, 649-658. doi: 10.1016/j.lwt.2018.04.017

Beganović, J., Kos, B., Pavunc, A. L., Uroić, K., Jokić, M., and Šušković, J. (2014). Traditionally produced sauerkraut as source of autochthonous functional and drafted the manuscript. All authors read and approved the final manuscript.

\section{FUNDING}

We are grateful to the University Grants Commission (Ref No: F.15-1/2015-17/PDFWM-2015-17-TEL37335, SAII) and Ministry of Human Resource Development, RUSA 2.0 Program, Government of India, for financial assistance to carry out this research work.

starter cultures. Microbiol. Res. 169, 623-632. doi: 10.1016/j.micres.2013. 09.015

Borse, B. B., Rao, L. J. M., Ramalakshmi, K., and Raghavan, B. (2007). Chemical composition of volatiles from coconut sap (neera) and effect of processing. Food Chem. 101, 877-880. doi: 10.1016/j.foodchem.2006.02.026

Caggia, C., De Angelis, M., Pitino, I., Pino, A., and Randazzo, C. L. (2015). Probiotic features of Lactobacillus strains isolated from Ragusano and Pecorino Siciliano cheeses. Food Microbiol. 50, 109-117. doi: 10.1016/j.fm.2015.03.010

Chandel, D., Sharma, M., Chawla, V., Sachdeva, N., and Shukla, G. (2019). Isolation, characterization and identification of antigenotoxic and anticancerous indigenous probiotics and their prophylactic potential in experimental colon carcinogenesis. Sci. Rep. 9:14769. doi: 10.1038/s41598-019-51361-z

Chinnamma, M., Bhasker, S., Binitha Hari, M., Sreekumar, D., and Madhav, H. (2019). Coconut neera- a vital health beverage from coconut palms: harvesting, processing and quality analysis. Beverages 5:22. doi: 10.3390/beverages 5010022

Choi, A.-R., Patra, J. K., Kim, W. J., and Kang, S.-S. (2018). Antagonistic activities and probiotic potential of lactic acid bacteria derived from a plant-based fermented food. Front. Microbiol. 9:1963. doi: 10.3389/fmicb.2018.01963

Coutiño, B., Flores, A. C., Vela-Gutiérrez, G., Sepúlveda, L., Aguilar, C. N., ChavezGonzalez, M., et al. (2020). "Tavern or coyol wine: a beverage from palm sap with biotechnological potential," in Biotechnological Progress and Beverage Consumption, eds A. M. Grumezescu, and A. M. Holban (Amsterdam: Elsevier), 233-252. doi: 10.1016/B978-0-12-816678-9.00007-2

Da Silva, L. A., Neto, J. H. P. L., and Cardarelli, H. R. (2019). Safety and probiotic functionality of isolated goat milk lactic acid bacteria. Ann. Microbiol. 69, 1497-1505.

de Albuquerque, T. M. R., Garcia, E. F., de Oliveira Araújo, A., Magnani, M., Saarela, M., and de Souza, E. L. (2018). In vitro characterization of Lactobacillus strains isolated from fruit processing by-products as potential probiotics. Probiotics Antimicrob. Proteins 10, 704-716. doi: 10.1007/s12602-017-9318-2

Dos Santos, M. S., Martendal, E., and Carasek, E. (2011). Determination of THMs in soft drink by solid-phase microextraction and gas chromatography. Food Chem. 127, 290-295. doi: 10.1016/j.foodchem.2010.12.115

EFSA Panel on Additives and Products or Substances used in Animal Feed (FEEDAP) (2012). Guidance on the assessment of bacterial susceptibility to antimicrobials of human and veterinary importance. EFSA J. 10:2740.

Elliott, D. A., Kim, W. S., Jans, D. A., and Garner, B. (2007). Apoptosis induces neuronal apolipoprotein-E synthesis and localization in apoptotic bodies. Neurosci. Lett. 416, 206-210. doi: 10.1016/j.neulet.2007.02.014

Ghosh, S., Chakraborty, R., and Raychaudhuri, U. (2015). Determination of pH-dependent antioxidant activity of palm (Borassus flabellifer) polyphenol compounds by photoluminol and DPPH methods: a comparison of redox reaction sensitivity. 3 Biotech 5, 633-640. doi: 10.1007/s13205-0140260-7

Gueimonde, M., Sánchez, B., de los Reyes-Gavilán, C. G., and Margolles, A. (2013). Antibiotic resistance in probiotic bacteria. Front. Microbiol. 4:202. doi: 10.3389/ fmicb.2013.00202

Haghshenas, B., Nami, Y., Abdullah, N., Radiah, D., Rosli, R., and Khosroushahi, A. Y. (2015). Anticancer impacts of potentially probiotic acetic acid bacteria isolated from traditional dairy microbiota. LWT Food Sci. Technol. 60, 690-697. doi: 10.1016/j.lwt.2014.09.058 
Ilavenil, S., Vijayakumar, M., Kim, D. H., Valan Arasu, M., Park, H. S., Ravikumar, S., et al. (2016). Assessment of probiotic, antifungal and cholesterol lowering properties of Pediococcus pentosaceus KCC-23 isolated from Italian ryegrass. J. Sci. Food Agric. 96, 593-601. doi: 10.1002/jsfa.7128

Joint FAO/WHO Expert Committee on Food Additives Meeting and World Health Organization (2006). Safety Evaluation of Certain Contaminants in Food, Vol. 82. Rome: Food \& Agriculture Organization.

Karthikeyan, R., Suresh Kumar, K., Singaravadivel, K., and Alagusundaram, K. (2014). Volatile elements of coconut toddy (Cocos nucifera) by gas chromatography-mass spectrometry. J. Chromatogr. Separat. Techniq. 5:213. doi: 10.4172/2157-7064.1000213

Lamba, J., Goomer, S., and Saxena, S. K. (2019). Study the lactic acid bacteria content in traditional fermented Indian drink: kanji. Int. J. Gastron. Food Sci. 16:100143. doi: 10.1016/j.ijgfs.2019.100143

Lasekan, O., and Abbas, K. A. (2010). Flavour chemistry of palm toddy and palm juice: a review. Trends Food Sci. Technol. 21, 494-501. doi: 10.1016/j.tifs.2010. 07.007

Lee, K.-E., and Kang, Y.-S. (2018). 1-Citrulline restores nitric oxide level and cellular uptake at the brain capillary endothelial cell line (TR-BBB cells) with glutamate cytotoxicity. Microvasc. Res. 120, 29-35. doi: 10.1016/j.mvr.2018.05.010

Lefebvre, D., Gabriel, V., Vayssier, Y., and Fontagne-Faucher, C. (2002). Simultaneous HPLC determination of sugars, organic acids and ethanol in sourdough process. LWT Food Sci. Technol. 35, 407-414.

Lei, E., Vacy, K., and Boon, W. C. (2016). Fatty acids and their therapeutic potential in neurological disorders. Neurochem. Int. 95, 75-84. doi: 10.1016/j.neuint. 2016.02.014

Li, F., Yin, Y., Tan, B., Kong, X., and Wu, G. (2011). Leucine nutrition in animals and humans: mTOR signaling and beyond. Amino Acids 41, 1185-1193. doi: 10.1007/s00726-011-0983-2

Li, P., Jia, S., Zhou, C., Fang, H., and Chen, C. (2017). Protective role of Lactobacillus fermentum R6 against Clostridium perfringens in vitro and in chicken breast meat under temperature abuse conditions. Innov. Food Sci. Emerg. Technol. 41, 117-123. doi: 10.1016/j.ifset.2017.03.001

Lim, T. K. (2012). "Borassus flabellifer," in Edible Medicinal and Non-Medicinal Plants, (Dordrecht: Springer), 293-300. doi: 10.1007/978-90-481-8661-7-44

Lin, X., Xia, Y., Wang, G., Xiong, Z., Zhang, H., Lai, F., et al. (2018). Lactobacillus plantarum AR501 Alleviates the oxidative stress of D-Galactose-induced aging mice liver by upregulation of Nrf2-mediated antioxidant enzyme expression. Journal of Food Science 83, 1990-1998. doi: :10.1111/1750-3841.14200

Mannapperuma, W., Abayasekara, C. L., Herath, G. B., Werellagama, D. R., and Tanski, H. H. (2011). Comparison of bacteriological methods for detecting and enumerating total coliforms and Escherichia coli in water. Res. J. Microbiol. 6, 851-861.

Mariselvam, R., Ignacimuthu, S., Ranjitsingh, A. J. A., and Mosae, S. P. (2020). An insight into leaf secretions of Asian palmyra palm: a wound healing material from nature. Mater. Today Proc. 9, 6937-6951. doi: 10.1016/j.matpr.2020. 05.393

Marroki, A., and Bousmaha-Marroki, L. (2014). Lactobacilli isolated from Algerian goat's milk as adjunct culture in dairy products. Braz. Arch. Biol. Technol. 57, 410-420. doi: 10.1590/S1516-89132014005000003

Monteagudo-Mera, A., Rodríguez-Aparicio, L., Rúa, J., Martínez-Blanco, H., Navasa, N., García-Armesto, M. R., et al. (2012). In vitro evaluation of physiological probiotic properties of different lactic acid bacteria strains of dairy and human origin. J. Funct. Foods 4, 531-541.

Morton, J. F. (1988). Notes on distribution, propagation, and products of Borassus palms (Arecaceae). Econ. Bot. 42, 420-441. doi: 10.1007/BF02860166

Nami, Y., Haghshenas, B., Haghshenas, M., Abdullah, N., and Yari Khosroushahi, A. (2015). The prophylactic effect of probiotic Enterococcus lactis IW5 against different human cancer cells. Front. Microbiol. 6:1317. doi: 10.3389/fmicb.2015. 01317

Nami, Y., Vaseghi Bakhshayesh, R., Mohammadzadeh Jalaly, H., Lotfi, H., Eslami, S., and Hejazi, M. A. (2019). Probiotic properties of Enterococcus isolated from artisanal dairy products. Front. Microbiol. 10:300. doi: 10.3389/fmicb.2019. 00300

Ni, K., Wang, Y., Li, D., Cai, Y., and Pang, H. (2015). Characterization, identification and application of lactic acid bacteria isolated from forage paddy rice silage. PLoS One 10:e0121967. doi: 10.1371/journal.pone. 0121967
Nur Aimi, R., Abu Bakar, F., and Dzulkifly, M. H. (2013). Determination of volatile compounds in fresh and fermented nipa sap (Nypa fruticans) using static headspace gas chromatography-mass spectrometry (GC-MS). Int. Food Res. J. $20,369-376$.

Oh, Y. J., and Jung, D. S. (2015). Evaluation of probiotic properties of Lactobacillus and Pediococcus strains isolated from Omegisool, a traditionally fermented millet alcoholic beverage in Korea. LWT Food Sci. Technol. 63, 437-444.

Pandey, K. R., Naik, S. R., and Vakil, B. V. (2015). Probiotics, prebiotics and synbiotics-a review. J. Food Sci. Technol. 52, 7577-7587. doi: 10.1007/s13197015-1921- 1

Perin, L. M., Miranda, R. O., Todorov, S. D., de Melo Franco, B. D. G., and Nero, L. A. (2014). Virulence, antibiotic resistance and biogenic amines of bacteriocinogenic lactococci and enterococci isolated from goat milk. Int. J. Food Microbiol. 185, 121-126.

Peter, H. B., Kazunori, M., Janice, A. V., and Sergei, P. B. (2010). "Reference module in chemistry, molecular sciences and chemical engineering," in Comprehensive Natural Products II, Vol. 5. eds Hung-Wen (Ben) Liu and Lew Mander, 469-530

Rayavarapu, B., Tallapragada, P., and Usha, M. S. (2019). Statistical optimization of $\gamma$-aminobutyric acid production by response surface methodology and artificial neural network models using Lactobacillus fermentum isolated from palm wine. Biocatal. Agric. Biotechnol. 22:101362. doi: 10.1016/j.bcab.2019.101362

Reshma, M. V., Jacob, J., Syamnath, V. L., Habeeba, V. P., Kumar, B. S. D., and Lankalapalli, R. S. (2017). First report on isolation of 2, 3, 4-trihydroxy-5methylacetophenone from palmyra palm (Borassus flabellifer Linn.) syrup, its antioxidant and antimicrobial properties. Food Chem. 228, 491-496. doi: 10. 1016/j.foodchem.2017.02.043

Reuben, R. C., Roy, P. C., Sarkar, S. L., Rubayet Ul Alam, A. S. M., and Jahid, I. K. (2020). Characterization and evaluation of lactic acid bacteria from indigenous raw milk for potential probiotic properties. J. Dairy Sci. 103, 1223-1237. doi: 10.3168/jds.2019-17092

Rokana, N., Singh, B. P., Thakur, N., Sharma, C., Gulhane, R. D., and Panwar, H. (2018). Screening of cell surface properties of potential probiotic lactobacilli isolated from human milk. J. Dairy Res. 85, 347-354. doi: 10.1017/ S0022029918000432

Saadat, Y. R., Khosroushahi, A. Y., and Gargari, B. P. (2019). A comprehensive review of anticancer, immunomodulatory and health beneficial effects of the lactic acid bacteria exopolysaccharides. Carbohydr. Polym. 217, 79-89. doi: 10.1016/j.carbpol.2019.04.025

Saitou, N., and Nei, M. (1987). The neighbor-joining method: a new method for reconstructing phylogenetic trees. Mol. Biol. Evol. 4, 406-425. doi: 10.1093/ oxfordjournals.molbev.a040454

Sanders, M. E., Merenstein, D. J., Reid, G., Gibson, G. R., and Rastall, R. A. (2019). Probiotics and prebiotics in intestinal health and disease: from biology to the clinic. Nat. Rev. Gastroenterol. Hepatol. 16, 605-616. doi: 10.1038/s41575-0190173-3

Sarah, M., Weaver, I. N., and Weaver, D. F. (2013). An evaluation of interindividual responses to the orally administered neurotransmitter $\beta$-alanine. J. Amino Acids 2013:429847. doi: 10.1155/2013/429847

Sharma, D., Saharan, B. S., Chauhan, N., Bansal, A., and Procha, S. (2014). Production and structural characterization of Lactobacillus helveticus derived biosurfactant. Sci. World J. 2014:493548. doi: 10.1155/2014/493548

Sharma, S., and Kanwar, S. S. (2017). Adherence potential of indigenous lactic acid bacterial isolates obtained from fermented foods of Western Himalayas to intestinal epithelial Caco-2 and HT-29 cell lines. J. Food Sci. Technol. 54, 3504-3511. doi: 10.1007/s13197-017-2807-1

Singhal, N., Maurya, A. K., Mohanty, S., Kumar, M., and Virdi, J. S. (2019). Evaluation of bile salt hydrolases, cholesterol-lowering capabilities, and probiotic potential of Enterococcus faecium isolated from rhizosphere. Front. Microbiol. 10:1567. doi: 10.3389/fmicb.2019.01567

Somashekaraiah, R., Shruthi, B., Deepthi, B. V., and Sreenivasa, M. Y. (2019). Probiotic properties of lactic acid bacteria isolated from Neera: a naturally fermenting coconut palm nectar. Front. Microbiol. 10:1382. doi: 10.3389/fmicb. 2019.01382

Sornplang, P., and Piyadeatsoontorn, S. (2016). Probiotic isolates from unconventional sources: a review. J. Anim. Sci. Technol. 58:26. doi: 10.1186/ s40781-016-0108-2

Srinivas, B., Rani, G. S., Kumar, B. K., Chandrasekhar, B., Krishna, K. V., Devi, T. A., et al. (2017). Evaluating the probiotic and therapeutic potentials of 
Saccharomyces cerevisiae strain (OBS2) isolated from fermented nectar of toddy palm. AMB Express 7:2. doi: 10.1186/s13568-016-0301-1

Szkudzińska, K., Smutniak, I., Rubaj, J., Korol, W., and Bielecka, G. (2017). Method validation for determination of amino acids in feed by UPLC. Accred. Qual. Assur. 22, 247-252. doi: 10.1007/s00769-017-1281-9

Tang, H., Qian, B., Xia, B., Zhuan, Y., Yao, Y., Gan, R., et al. (2018). Screening of lactic acid bacteria isolated from fermented Cornus officinalis fruits for probiotic potential. J. Food Saf. 38:e12565. doi: 10.1111/jfs.12565

Tapsoba, F., Savadogo, A., Legras, J., Zongo, C., and Traore, A. S. (2016). Microbial diversity and biochemical characteristics of Borassus akeassii wine. Lett. Appl. Microbiol. 63, 297-306. doi: 10.1186/s13568-0160301-1

Tayade, A. B., Dhar, P., Kumar, J., Sharma, M., Chaurasia, O. P., and Srivastava, R. B. (2017). Trans-Himalayan Rhodiola imbricata Edgew. root: a novel source of dietary amino acids, fatty acids and minerals. J. Food Sci. Technol. 54, 359-367. doi: 10.1007/s13197-016-2469-4

Vuotto, C., Longo, F., and Donelli, G. (2014). Probiotics to counteract biofilmassociated infections: promising and conflicting data. Int. J. Oral Sci. 6, 189-194. doi: 10.1038/ijos.2014.52

Wang, J., Yang, K., Liu, M., Zhang, J., Wei, X., and Fan, M. (2018). Screening for potential probiotic from spontaneously fermented non-dairy foods based on in vitro probiotic and safety properties. Ann. Microbiol. 68, 803-813.

Xiao, P., Huang, Y., Yang, W., Zhang, B., and Quan, X. (2015). Screening lactic acid bacteria with high yielding-acid capacity from pickled tea for their potential uses of inoculating to ferment tea products. J. Food Sci. Technol. 52, 6727-6734.

Xing, J., Wang, G., Zhang, Q., Liu, X., Gu, Z., Zhang, H., et al. (2015). Determining antioxidant activities of lactobacilli cell-free supernatants by cellular antioxidant assay: a comparison with traditional methods. PLoS One 10:e0119058. doi: 10.1371/journal.pone.0119058

Yadav, R., Puniya, A. K., and Shukla, P. (2016). Probiotic properties of Lactobacillus plantarum RYPR1 from an indigenous fermented beverage Raabadi. Front. Microbiol. 7:1683. doi: 10.3389/fmicb.2016.01683

Yasmin, I., Saeed, M., Khan, W. A., Khaliq, A., Chughtai, M. F. J., Iqbal, R., et al. (2020). In vitro probiotic potential and safety evaluation (Hemolytic, Cytotoxic Activity) of Bifidobacterium strains isolated from raw camel milk. Microorganisms 8:354.

Zeid, I. M. A., and FarajAlla, A. R. A. (2019). "Borassus flabellifer L. palmyra palm (Daleeb): biochemistry, functions and utilization," in Wild Fruits: Composition, Nutritional Value and Products, ed. A. Mariod (Cham: Springer), 465-479.

Zommiti, M., Bouffartigues, E., Maillot, O., Barreau, M., Szunerits, S., Sebei, $\mathrm{K}$, et al. (2018). In vitro assessment of the probiotic properties and bacteriocinogenic potential of Pediococcus pentosaceus MZF16 isolated from artisanal Tunisian meat “Dried Ossban.”. Front. Microbiol. 9:2607. doi: 10.3389/ fmicb.2018.02607

Conflict of Interest: The authors declare that the research was conducted in the absence of any commercial or financial relationships that could be construed as a potential conflict of interest.

Copyright (C) 2021 Pammi, Bhukya, Lunavath and Bhukya. This is an open-access article distributed under the terms of the Creative Commons Attribution License (CC BY). The use, distribution or reproduction in other forums is permitted, provided the original author(s) and the copyright owner(s) are credited and that the original publication in this journal is cited, in accordance with accepted academic practice. No use, distribution or reproduction is permitted which does not comply with these terms. 